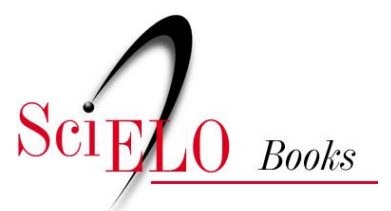

\title{
Relatório reforma do judiciário
}

\author{
Paulo César Carbonari
}

CARBONARI, PC., org. Relatório reforma do judiciário [online]. Rio de Janeiro: Centro Edelstein de Pesquisa Social, 2010, 78 p. ISBN 978-85-7982-030-4. Available from SciELO Books $<$ http://books.scielo.org $>$.

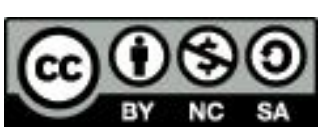

All the contents of this chapter, except where otherwise noted, is licensed under a Creative Commons Attribution-Non Commercial-ShareAlike 3.0 Unported.

Todo o conteúdo deste capítulo, exceto quando houver ressalva, é publicado sob a licença Creative Commons Atribuição Uso Não Comercial - Partilha nos Mesmos Termos 3.0 Não adaptada.

Todo el contenido de este capítulo, excepto donde se indique lo contrario, está bajo licencia de la licencia Creative Commons Reconocimento-NoComercial-CompartirIgual 3.0 Unported. 


\section{BIBLIOTECA VIRTUAL DE CIÊNCIAS HUMANAS}

\section{RELATÓRIO}

REFORMA DO JUDICIÁRIO

\section{Paulo César Carbonari Organizador}


Paulo César Carbonari

Organizador

Relatório

\section{Reforma do judiciário}

Esta publicação é parte da Biblioteca Virtual de Ciências Humanas do Centro Edelstein de Pesquisas Sociais - www.bvce.org

Copyright (c) 2010 Paulo César Carbonari

Copyright (c) 2010 desta edição on-line: Centro Edelstein de Pesquisas Sociais Ano da última edição: 2004 - Instituto de Acesso à Justiça, Porto Alegre

Nenhuma parte desta publicação pode ser reproduzida ou transmitida por qualquer meio de comunicação para uso comercial sem a permissão escrita dos proprietários dos direitos autorais. A publicação ou partes dela podem ser reproduzidas para propósito não comercial na medida em que a origem da publicação, assim como seus autores, seja reconhecida.

\section{ISBN 978-85-7982-0304}

Centro Edelstein de Pesquisas Sociais

www. centroedelstein.org.br

Rua Visconde de Pirajá, 330/1205

I panema - Rio de Janeiro - RJ

CEP: 22410-000. Brasil

Contato: bvce@centroedelstein.org.br 


\section{Sumário}

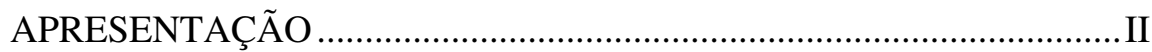

INTRODUÇÃO .............................................................................

1. DIÁLOGOS DE ABERTURA ........................................................... 3

Cláudio Bladino Maciel ....................................................................3

Pier Paolo Bottini ......................................................................5

Lia Freitas Cavalcante............................................................. 7

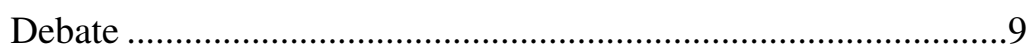

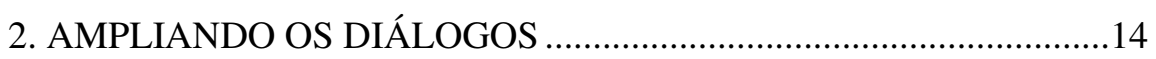

PRIMEIRA PARTE .........................................................14

José Aquino Flores de Camargo ...............................................14

Oscar Vilhena Vieira...........................................................15

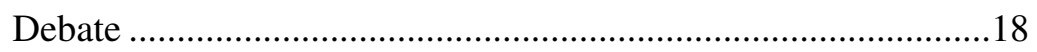

SEGUNDA PARTE ..........................................................20

Juçara Dutra Vieira .........................................................20

Virgínia Feix ..................................................................23

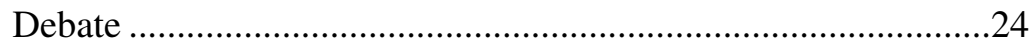

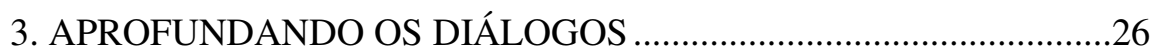

Maria Tereza Sadek.............................................................26

Charles Roberto Pranke............................................................43

José Eduardo Martins Cardozo ................................................44

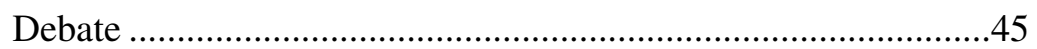

4. CONTINUANDO OS DIÁLOGOS .................................................49

PRIMEIRA PARTE .......................................................... 49
Selma Teixeira da Silva.................................................... 49

Marcelo Semer .................................................................... 55

Debate......................................................................... 56

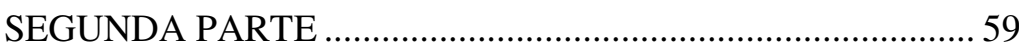

Quintino Severo.................................................................... 59

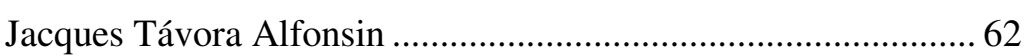

5. SISTEMATIZANDO OS DIÁLOGOS............................................ 68

5.1. Diagnóstico do Judiciário e do Acesso à Justiça .................. 68

5.2. Reformar o Judiciário? ............................................... 72

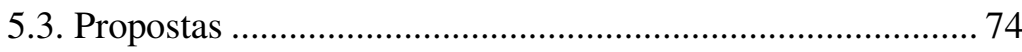




\section{APRESENTAÇÃO}

O Instituto de Acesso à Justiça (IAJ), fundado em outubro de 2002, sustenta seu exercício cotidiano na difusão da cultura dos direitos humanos e no acesso à justiça para a população social, econômica e culturalmente desassistida.

No Brasil, a movimentação pela Reforma do Judiciário, em andamento, passa ao largo da sociedade civil. Por isso, o IAJ promoveu o seminário sobre a Reforma do Poder Judiciário com a finalidade de debater e discutir a justiça brasileira justamente na perspectiva da sociedade civil destinatária dos seus serviços.

O IAJ acredita que, por meio de um canal de diálogo que se estabeleça entre a sociedade civil e especialistas no tema em questão, possam ser respondidas algumas indagações acerca do acesso à justiça no Brasil: a nossa população conhece e tem acesso ao seu Judiciário? O Judiciário existente responde às demandas da sociedade à qual se destina? Existe convergência e dados objetivos sobre o significado do "acesso à justiça" em uma sociedade democrática? O que precisa acontecer para a efetividade do acesso à justiça no Brasil?

Para tanto, o IAJ convidou e reuniu, nos dias 24 e 25 de novembro de 2003, no Hotel Embaixador, em Porto Alegre, representantes de diversas organizações da sociedade civil e de especialistas para que discutissem essas questões.

A todos os painelistas foi sugerida uma abordagem geral sobre a reforma do judiciário que contemplasse ao menos os seguintes aspectos: a) o Judiciário que temos e o Judiciário que queremos, visando a um diagnóstico de sua situação e concepção e que levasse em conta, para a análise, critérios como adequação, consistência/coerência, agilidade, credibilidade, efetividade e acesso; b) as razões para uma eventual reforma: por que, para quê? Em que amplitude e em que limites deveria dar- se; c) a ampliação do acesso à justiça, o acesso inexistente e a indispensável assistência legal.

Com esta publicação, o IAJ pretende contribuir para o debate de modo a ampliar a discussão sobre a justiça brasileira com as necessárias e urgentes manifestações da sociedade civil. 
É fundamental registrar que este documento e o evento que lhe deu origem fazem parte do Projeto Re-Vivendo a Liberdade, financiado pela Fundação Ford. O IAJ agradece esse fazer acontecer a partir da dedicação e da competência de Denise Dourado Dora.

Agradecemos, igualmente, ao Relator do Seminário, Paulo César Carbonari, por seu trabalho profissional de sistematização do Relatório e, sobretudo, às instituições parceiras tão importantes para a concretização e o sucesso do Seminário sobre Reforma do Judiciário: a sociedade civil discute a sua justiça.

\section{João Abílio de Carvalho Rosa \\ Coordenador Executivo}

IAJ

Porto Alegre, março de 2004

\section{Sonia Biehler da Rosa \\ Marcelo Sgarbossa}

Centro de Estudos e de Pesquisa

IAJ

\section{INTRODUÇÃO}

O debate sobre o acesso à justiça, além de oportuno no seio da reforma do Judiciário, é estratégico na perspectiva da promoção dos direitos humanos. Além de ser um direito humano fundamental, o acesso à justiça é uma das condições para garantir a efetividade do conjunto dos direitos humanos. Uma sociedade que não garante o acesso à justiça dificilmente pode se dizer uma sociedade que efetivamente atingiu um Estado Democrático de Direito.

Além de entender o acesso à justiça como acesso ao poder judiciário, à luz dos direitos humanos, podemos perfeitamente alargar a noção e dizer que está em jogo gerar condições de acesso ao conjunto dos requisitos e materialidades necessárias à realização da dignidade da pessoa humana. $\mathrm{O}$ acesso à justiça, a rigor, exige o acesso a todos os direitos humanos como instrumentos e mecanismos de efetivação de tempos e espaços que realizem a dignidade de todos/as os/as humanos/as. Por isso que ampliar e qualificar o acesso à justiça é pretender a qualificação e o alargamento do Estado Democrático de Direito, é pretender avanços na sua realização efetiva e inclusiva, sem com isso nivelar ou tornar opaca a diversidade da sociedade. Pelo contrário, a igualdade formal só tem sentido se for invertida como igualdade na diversidade, portanto, como igualdade real.

Esta é a mensagem de fundo para a qual os debates realizados, e aqui registrados, aponta. Em quatro painéis, lideranças sociais das mais diversas organizações da sociedade civil apresentaram suas inquietações, suas leituras, suas posições e suas propostas. Elas são convergentes no espírito, mas ainda divergentes em muitas veredas. Assim é mesmo, a sociedade civil preza por demais a diversidade e não se incomoda em se apresentar colocando-se sem muitos consensos. Ela acredita e aposta no debate democrático, na divergência de ideias, na busca comum de alternativas, nem sempre imediatamente identificáveis. Por isso que todos os painéis têm o mesmo nome, diálogos. Assim mesmo, o que está e precisa ser ampliado é o diálogo sobre o acesso à justiça. Mais do que formular ou pinçar propostas específicas, o fundamental é dar atenção às análises, aos argumentos, às preocupações. Delas podem emergir muitas propostas criativas e inovadoras, como efetivamente se pode ler e identificar ao longo dos registros. 
Temos certeza de que estes debates, mais do que um evento, configuram-se como um processo amplo e que quer ser ainda mais amplo, cientes de que somente será alargado na medida em que efetivamente forem sendo criadas as condições concretas para realizar o acesso à justiça.

Finalmente, nosso profundo agradecimento ao IAJ, na pessoa de seu coordenador, João Abílio. O convite para participar e para relatar o debate produziu mais do que uma tarefa técnica, produziu uma convivência e uma cumplicidade que gera compromisso fecundo na luta pelos direitos humanos. Conhecer as pessoas do IAJ foi como estabelecer uma relação com companheiros que se tornam parte da gente pela fraternidade que congrega os que lutam pelos direitos humanos. Parafraseando Saramago, a convivência que temos tido renova nossa crença de que temos direito à solidariedade e o dever de ser solidários e que não há qualquer incompatibilidade entre a firmeza das próprias convicções e o respeito às convicções dos outros. E mais, continuando com Saramago, a vivenciar que estamos todos feitos da mesma carne sofrente e que lutamos incansavelmente para que um dia possamos chegar a ser verdadeiramente humanos. Muito Obrigado.

\section{Paulo César Carbonari}

Coordenador Nacional de Formação do Movimento Nacional de Direitos Humanos (MNDH)

Relator do Seminário

\section{DIÁLOGOS DE ABERTURA}

O Painel abriu os trabalhos do Seminário e foi coordenado pelo Dr. João Abílio, coordenador geral do Instituto de Acesso à Justiça (IAJ). Foram expositores no Painel: Cláudio Baldino Maciel (presidente da Associação dos Magistrados Brasileiros - AMB), Pier Paolo Bottini (representante da Secretaria de Reforma do Poder Judiciário do Ministério da Justiça) e Lia Freitas Cavalcante (representante da Associação Brasileira de Organizações Não Governamentais - ABONG e membro do Observatório do Judiciário do Ceará). O Painel foi realizado na manhã do dia 24 de novembro, das 9:30 às 12 horas.

\section{CLÁUDIO BLADINO MACIEL}

(Associação dos Magistrados Brasileiros - AMB)

Traz a visão de um magistrado, que atua exclusivamente na Magistratura, a experiência da vida de juiz e de líder associativo dos magistrados. Tem a ótica de quem vê o judiciário por dentro. Ponto de vista comprometido, seguramente, por um certo corporativismo próprio da atividade associativa. Tem a vantagem de conhecer significativamente o poder judiciário.

Afirma que a estrutura constitucional do poder judiciário brasileiro é uma boa estrutura. O Judiciário tem todas as condições de ser um Poder em todos os sentidos que o qualificam. O Poder Judiciário é mais do que um órgão encarregado de julgar conflitos interpessoais; ele é um dos poderes republicanos, componente do sistema de freios e contrapesos entre os poderes.

O Poder Judiciário conta com duas formas de ação do controle judicial: a) Uma difusa - na figura de cada juiz que tem autonomia para aplicar ou não a lei dentro do sistema judiciário; b) Outra concentrada - nos tribunais superiores (Supremo Tribunal Federal - STF, especialmente), que têm poder de tirar a lei do mundo jurídico, pela inconstitucionalidade (via Ação Direta de Inconstitucionalidade - ADIN, especialmente).

O perfil constitucional é bom. Mas ele contrasta com a cultura nele presente, que o transforma num poder muito conservador e refratário às mudanças. É de sua natureza agir retrospectivamente. Diferindo dos outros 
poderes, que agem prospectivamente. Por esta razão, muitos processos foram invalidados tomando em conta simplesmente motivos processuais e formais (por exemplo, por não ter sido feita a publicação de edital no átrio do Foro). Ademais preocupa-se em desenvolver julgamentos bem formulados e bem fundamentados, o que exige tempo e não necessariamente responde imediatamente à situação. Isto contrasta com o fato de que a sociedade atual é dinâmica e exige respostas vinculadas à situação, mais pragmáticas do que ideais. Por tudo isso, redunda-se num dos principais problemas do Judiciário, a morosidade. Ela o torna mais temido do que respeitado pela população.

A Reforma do Judiciário vem sendo discutida pela sociedade. Infelizmente, no entanto, há neste debate uma certa causa punitiva - se vier nesta perspectiva pode ser ruim. As propostas e o debate precisam estar baseados na análise da situação atual e nas expectativas do Poder que se quer.

A crise do Poder Judiciário é de funcionalidade. Entre os fatores que a determinam, podemos citar: a) legislação abundante e anárquica, inclusive com legislações que não têm apelo popular e por isso não são aplicadas; b) estrutura de funcionalidade do poder judiciário, excessivamente burocrática; c) instrumentos carentes com processualística exagerada - o percurso precisaria ser mais simples, rápido e útil, superando a centralidade maior no processo do que no mérito - o que torna o trabalho judicial uma disfuncionalidade impressionante.

Isto ocorre porque há interesses de que processos demorem, que se protelem decisões. Há fortes interesses de reserva de mercado de trabalho dos operadores da Justiça. Tanto que todos querem uma justiça ágil, mas a mudez dos interesses se esconde inclusive atrás do apoio a esta proposta.

A morosidade é dramática para o juiz. Ele não ganha, só perde em conceito e credibilidade. Em pouco tempo se depara com um drama ético. Mesmo que julgue bem, e muitos processos, depara-se com as demandas que poderia deixar de julgar com implicações diretas na vida das pessoas e que não consegue julgar ou que, quando vai fazê-lo, já é tão tarde que perde sentido sua decisão.

Processo é uma teatralização. O litígio já está no passado. Ele reconstrói teatralmente o acontecimento. O juiz está fora do mundo real, do contato com o mundo real. O oficial de justiça é que tem o contato direto com a realidade. O juiz não tem este contato, mas precisa de profunda empatia com o processo, com o que está no processo, para poder reconstruir permanentemente sua humanidade no processo. "Para sentir o morto temos que ver o morto", diz Camus, em A Peste. Quando o juiz está abarrotado de processos, corre o risco de perder esta empatia e este compromisso ético, estando alienado da realidade no ato do julgamento.

Sistema de punições da ação do juiz tem que ser razoável. O problema é que hoje permite que, depois de condenado, um juiz seja afastado com vencimentos. É necessário mudar a legislação.

Ademais, é necessário um sistema concentrado de planejamento e de monitoramento administrativo do Poder Judiciário, com instâncias disciplinares. Para superar situações dispares presentes e para garantir uma base mais científica e de mérito, é necessário superar a atuação empirista e centrada na longevidade. Não dá para conviver com gestões que não sejam vocacionadas para tal. Romper o modelo do revezamento dos mais antigos; superar o ilhamento da administração dentro do próprio poder judiciário; introduzir mecanismos de cobrança de atingimento de metas e de controle são medidas urgentes. Proposta para mudar isso: eleição dos presidentes de Tribunais feita com participação direta de todos os juízes. Da mesma forma, os orçamentos deveriam ser tratados tecnicamente e com participação e controle. Necessário também qualificar a capacidade administrativa dos juízes.

Finalmente, o modelo de autonomia entre poderes - importado por Rui Barbosa dos EUA- é fundamental para fortalecer a democracia. A proposta de um Conselho Nacional de Justiça é experiência de matriz europeia, que tem um sistema parlamentarista e na qual o poder judiciário não é poder e sim serviço de alta relevância pública. Diferente de uma situação em que o Poder Judiciário é um dos poderes republicanos, como é o caso brasileiro. Por isso é preciso refletir e ponderar bem a questão do controle externo do Judiciário.

\section{PIER PAOLO BOTTINI}

(Secretaria Reforma Poder Judiciário do MJ)

Justifica a impossibilidade da presença do Secretário, ressalta a importância da discussão da sociedade civil sobre o tema. Fará uma 
exposição considerando os seguintes aspectos: O que se quer reformar? Quem são os agentes legítimos para fazer a reforma? Que reforma queremos?

$\mathrm{O}$ que se quer reformar.

Trata-se de reformar o Sistema Judicial Brasileiro, mais do que o Poder Judiciário (isto implica levar em conta Ministério Público, Defensorias, Procuradorias, Advocacia, Poder Legislativo, Poder Executivo). Importância do papel da sociedade civil organizada no sentido de promover o acesso à justiça - especialmente na politização e mobilização da sociedade.

\section{Quem é legítimo.}

Todos os atores que participam do sistema judicial são legítimos para propor reformas nele.

Que queremos reformar?

$\mathrm{O}$ aspecto central é o da independência. Ademais o Sistema tem que ser acessível - aproximar ao cidadão; Ser eficiente - como garantia da justiça; ser democrático - passando por todos os seus agentes; e Transparente.

\section{Papel da Secretaria da Reforma do Judiciário do Ministério da Justiça.}

1. Diagnosticar o funcionamento do Sistema Judicial, já que é estratégico para o desenvolvimento do país e para planejá-lo e direcioná-lo. Identificação dos gargalos e das experiências bem sucedidas. Neste sentido, está em curso um estudo que vem sendo feito pela Fundação Getúlio Vargas de São Paulo; e também diagnóstico dos juizados especiais. O Prêmio lnnovare visa dar reconhecimento e visibilidade às melhores práticas das atividades judiciais.

2. Implementação de modernização administrativa - que não demande alterações legais. Pode-se discutir e trabalhar, por exemplo, a expansão das melhores práticas; repensar o papel do Poder Executivo, que é o maior demandante do sistema judicial (hoje com $80 \%$ das ações) - grupo interministerial está discutindo padrões de conduta para resolução de conflitos em fóruns que não seja necessariamente o poder judiciário - além de; repensar a autonomia das Defensorias e Procuradorias, hoje dependente do Executivo. É a chamada "reforma silenciosa".

3. Acompanhamento das alterações legislativas sobre o sistema judicial: a) as infraconstitucionais e b) as constitucionais. Nas primeiras, trabalha-se com duas propostas: a) Alternativas de mediação, com a institucionalização de institutos de mediação judicial e extrajudicial, baseados na ideia do consenso - já tem um Anteprojeto pronto para ser encaminhado ao parlamento. b) Processo de execução civil, que não macula o devido processo legal. No nível das reformas constitucionais, faz-se acompanhamento da PEC 96/92 (hoje PEC 29/02, no Senado, relatada pelo Senador José Jorge). Há uma comissão do Ministério da Justiça encarregada de analisar o assunto. Chegou a cinco pontos: a) criação Conselho Nacional de Justiça e do Ministério Público; b) quarentena de três anos na saída para juízes; c) unificação dos critérios de ingresso na Magistratura e no Ministério Público, com pelo menos três anos de experiência na área; d) federalização dos crimes contra direitos humanos, especificamente alguns crimes mais específicos e contundentes; e) autonomia às defensorias públicas em nível constitucional.

Finalmente, reafirma a importância de discutir o Sistema Judicial, mais do que o Poder Judiciário. Está satisfeito por ver que o assunto está na pauta da sociedade civil.

\section{LIA FREITAS CAVALCANTE}

(Associação Brasileira de Organizações Não Governamentais)

Agradece o convite. Considera um dos temas centrais e relevantes para toda a sociedade brasileira. Falará do lugar das Organizações Não Governamentais (ONGs). A sociedade civil é ampla e com agregação de diferentes formas organizativas. Neste amplo campo, a ABONG se destaca pela ótica da democratização e da participação em vista da transformação da realidade social. Neste contexto, quer um judiciário democrático, transparente e aberto às demandas da sociedade. 
As ONGs atuam na perspectiva da efetivação de direitos, na interlocução e na demanda de direitos ao poder judiciário. Considerando estes aspectos, abordará os pontos que seguem.

a) Conhecimento dos direitos e do Judiciário: Somente se busca a reparação ou a promoção se há conhecimento de que demandas concretas constituem-se em direitos. O próprio acesso à justiça é direito. A percepção do direito pela população é fundamental. É também necessário conhecer o direito e o caminho do acesso à justiça. Nos últimos anos, tem havido ampliação da compreensão do direito por exemplo, de que os Direitos Humanos Econômicos, Sociais e Culturais (DhESC) são direitos demandáveis, mais do que meros serviços. Porém, estes direitos ainda não são respeitados como direitos - saúde, trabalho e alimentação, por exemplo, ainda não são reconhecidos com tal status. As pessoas não precisam saber de direito para se sentir injustiçadas, mas precisam conhecer o Direito para buscar a justiça.

b) Defesa técnica é fundamental, mesmo que possamos criar condições de mediação em outros níveis. Para isso é fundamental ampliar a capacidade de ação das Defensorias Públicas. A Defensoria Pública está enfraquecida na maior parte dos estados brasileiros, especialmente nas comarcas do interior. Esta situação precisa mudar.

c) Poder Judiciário. Um estudo feito em 1996, no Ceará, indicou que dos 40 homicídios dolosos ocorridos em 1994, somente um julgamento havia sido realizado dois anos depois e os outros estavam parados ou arquivados. Pessoas comuns têm dificuldade de acesso e de compreensão da Justiça. A morosidade produz injustiça. Ademais, há situações de corrupção e de tráfico de influência no Poder Judiciário. $\mathrm{O}$ Observatório do Judiciário do Ceará é uma rede informal de organizações independentes e pessoas que monitoram a ação do judiciário. As denúncias que o Observatório levantou convergiam para grupo específico de 30 magistrados dos mais de 300 existentes. Houve muita pressão, houve averiguações, mas os procedimentos foram atropelados (não houve direito de contraditório e ampla defesa) e por isso os dois desembargadores que haviam sido afastados neste movimento acabaram reintegrados. Em linhas gerais, o Judiciário dá prioridade clara às ações individuais e patrimoniais, em detrimento das coletivas e das que têm centralidade na pessoa. É fundamental o controle externo e há necessidade de urgente revisão da estrutura cartorial que emperra sobremaneira o Judiciário.

\section{DEBATE}

Quintino (CUT-RS): Pergunta a Cláudio Maciel: se o Brasil tem uma boa estrutura constitucional, por que tanta jurisprudência e por que não se amplia o uso da Constituição? Comentou que se surpreendeu com a questão dos juízes serem afastados com percepção dos vencimentos - os trabalhadores em geral, por falta grave, são imediatamente afastados, sendo suspensos os salários

Maciel (AMB): Ressalta que o afastado não pode exercer qualquer tipo de atividade. Mas, mesmo assim, manter a percepção de vencimentos não é a melhor saída. Na questão da jurisprudência, dois fenômenos: a Constituição é descritiva em matéria de direitos, havendo novos direitos sem uma sistemática e sistematização - interesses dilatórios - amplia o sentido da lei e depois entrega ao judiciário para interpretar e decidir. É contra a súmula com efeito vinculante. Melhor direito se cria na ponta. A consequência é a falta de homogeneidade nas decisões. Mas, a sociedade não é homogênea. Os investidores internacionais querem previsibilidade mais do que justiça. Por isso, é que há a ideia da súmula vinculante. Em boa parte, a reforma do judiciário está vinculada à funcionalidade do judiciário à economia. Esta visão é um equívoco. Judiciário tem obrigação com justiça em não com a economia. Custo Democracia, contra o custo Brasil. Democracia tem custo e as instituições devem funcionar não necessariamente a favor da macroeconomia. A economia escravizou a Política e quer escravizar o Direito. A força da economia está jogando por terra questões valiosas. Isto tem reduzido expectativas políticas e até frustrado do ponto de vista da ação na condução da economia. Direito tem que ser útil à ética. Questão da opinião pública tem que ser levada em conta. Mas, as decisões têm que ser tomadas sob o ponto de vista técnico. Estamos escravizados demais pela economia e há medo de que a reforma do judiciário seja conduzida sob este ponto de vista. $\mathrm{O}$ que a lide hegemônica da reforma do Judiciário quer é previsibilidade e maior coerção no cumprimento dos contratos. 
Carmem (Themis): O painel apresentou visões distintas que se complementam. O que há de convergência na mesa é que temos que produzir mudanças. A divergência está na abrangência e na forma de fazer a reforma. Reforma do Judiciário tem implicações internacionais. As propostas vêm sendo feitas em todos os países da América Latina, no sentido de julgamento de decisões comerciais por tribunais internacionais e não os tribunais constitucionais nacionais. Outra é a necessidade de mudança interna. Há necessidade de mudar também o processo criminal e não somente o civil. A Composição dos tribunais superiores feita pelo Executivo gera um vínculo estreito aos governantes e afeta sua autonomia.

Maciel $(A M B)$ : A avaliação é correta. É necessário repensar e mudar a forma de escolha dos Ministros do Supremo Tribunal Federal (STF). O STF caça atos dos demais poderes. Constituição é limitação de poderes e, por isso, o STF é tribunal político. Não é eleito. Retira sua legitimidade indiretamente dos demais poderes (já que é escolhido por outros poderes), não sendo assim, deveria ser via eleição direta. $O$ atual sistema repousa sobre aspectos relevantes. Acha, no entanto, que o Legislativo tem que ampliar seu papel na escolha, talvez incluindo a Câmara ou pela via de indicação por listas tríplices.

Lia $(A B O N G)$ : A ABONG não tem uma discussão sistemática sobre o tema. Mas, vai se posicionar a partir da experiência acumulada. A ideia de quarentena de saída ou de entrada poderia avançar. No futuro, talvez a eleição direta possa ser discutida.

Pier (SRJ-MJ): Concorda em discutir a quais interesses a Reforma pode responder. Governo atual é contra a súmula vinculante: celeridade a favor do cidadão é importante, mas em nome dela não se pode comprometer a democracia. Alterações do processo criminal: é fundamental contrastar sempre a celeridade com o direito à ampla defesa e contraditório. Estão sendo discutidas varas de execução penal de adolescentes em conflito com a lei, introdução de mediação via consenso, havendo condições de acesso quando ele não fosse atingido, entre outras medidas.

Encarnación (Movimento Comunitário): Como veem a proposta da redução da idade penal? Acesso à justiça é direito de todos, porque ele é tão difícil e os pobres são discriminados em todos os aspectos, inclusive com descaso e ampla burocracia? E a questão da humanização do atendimento e da igualdade no atendimento e na distribuição da justiça?

Lia $(A B O N G)$ : A redução da idade penal sempre aparece em momentos de espetacularização de crimes, via mídia. As medidas socioeducativas previstas no Estatuto da Criança e do Adolescente (ECA) precisam ser realizadas. O Estado de São Paulo é responsável por mais de $50 \%$ das medidas de internação e um dos que menos aplica as medidas socioeducativas, a Febem paulista somente reproduz os absurdo do sistema prisional. Acha que o ECA precisa ser aplicado. Deve-se repensar a banalização das medidas de internação. Ressalta a Importância de aplicação de medidas mais simples, combatendo impunidade.

Maciel ( $A M B$ ): Existe quase que um dogma na sociedade: a esquerda acha que não pode haver endurecimento penal, pois isso depõe contra a ideia de humanidade. Não podemos, no entanto, conviver com um sistema penal e prisional como o que temos. Não há nenhuma indicação de que a redução da idade penal vá resolver o problema. O problema é oferecer futuro digno para a juventude. A Defensoria Pública teria que ter um status independente. Pobre não tem cultura de resguardar-se (arquivar documentos, por exemplo) e acaba penalizado. Trata-se da opção política e econômica que temos. Humanização do Judiciário: O juiz precisa falar com as pessoas, estar próximo da sociedade.

Pier (SRJ-MJ): Reduzir a idade penal exige mudar a Constituição (pode chocar com as cláusulas pétreas), além dos aspectos materiais. A questão das mediações é fundamental, exemplo de Centros de Integração da Cidadania. Estado precisa estar presente na sociedade, próximo da sociedade e da população carente.

Magali (Sindjus-RS): Há um crescente de ampliação do acesso à justiça, inclusive com entrada de escritórios das faculdades, e Rondas da Cidadania. Número de ingresso de processos tem sido ampliado, inclusive nos recursos. Celeridade pode afastar a humanização. Dr. Maciel, qual sua opinião sobre a súmula vinculante?

Maciel $(A M B)$ : A única virtude da súmula vinculante é ampliar celeridade, mas tem um volume de efeitos contrários fundamentais. Facilita a vida do juiz, mas fere princípios constitucionais como devido processo legal, contraditório e inverte a criação da jurisprudência - redunda em 
jurisprudência preta poder. Numa sociedade dinâmica, é fundamental que a sociedade tenha mecanismos novos. A AMB propõe a súmula impeditiva de procedimento. Sobre a federalização dos crimes contra direitos humanos, ressalta que direitos humanos não é conceito jurídico. Fazer isso via Ministério Público, com o Procurador Geral tendo papel de decidir o foro para tal pode consagrar tribunal de exceção, depois do fato acontecido. Ademais, a Justiça Federal não tem capilaridade.

João Abílio (IAJ): Este argumento liquida com a ideia de federalização de competência em crimes contra os direitos humanos. Se os direitos humanos são abrangentes e importantes, por isso a competência para julgá-los tem que ser alargada para todos os juízes e em todas as instâncias. Juiz federal não necessariamente dá maior gravidade e seriedade.

Milene: Pede um posicionamento sobre a proposta de depoimento a distância?

Pier (SRJ-MJ): Pondera que a questão do deslocamento no caso de processos já abertos não é tão nova, pois há possibilidade de desaforamento. No caso dos crimes contra os direitos humanos, a proposta é que, mesmo que caiba ao Ministério Público Federal pedir, é ao Superior Tribunal de Justiça a quem cabe decidir. Isto não prejudica o livre posicionamento do juiz. Pensa que a presença do juiz no depoimento é fundamental, não sendo assim, pode atrapalhar o contraditório e a ampla defesa. Talvez seja melhor pensar em deslocar o juiz.

Paulo (MNDH): Sobre a questão da justiciabilidade dos direitos humanos. Pensa que isto implica uma concepção alargada de direitos humanos e em avançar para que eles ingressem cada vez mais nos processos judiciais sem que se esgotem nisso. Por outro lado, entende que é preciso avançar também no tratamento específico e técnico do tema, sendo que a questão não se resume a federalizar crimes contra eles. Entende que questões fundamentais como: Como trabalhar para que o Judiciário tenha um papel central na proteção dos direitos humanos? Qual é o limite do Judiciário na resolução de conflitos sociais? são fundamentais.

Maciel (AMB): Os litígios que estão na justiça em geral são falsos. Não deveriam estar em juízo. Há uma disfuncionalidade da qual as pessoas se servem, de má fé. Concorda com avaliação feita sobre o tema dos direitos humanos. O Poder Judiciário age por provocação e isto amarra sua ação. O atual sistema penal híbrido é ruim (polícia investiga, Ministério Público denuncia, Judiciário julga, Executivo executa a pena). Nisso talvez se tenha que pensar em juizados de instrução, ou, no mínimo, o Ministério Público participar mais da produção da prova. 


\section{AMPLIANDO OS DIÁLOGOS}

O Painel esteve sob a coordenação de Clédis R. de Souza, do Conselho Estadual de Desenvolvimento da Comunidade Negra (CODENE), no qual participa como representante das Comunidades Quilombolas. Da primeira parte, participaram: José Aquino Flores de Camargo (presidente da Associação dos Juízes do Rio Grande do Sul - AJURIS, desembargador do TJ-RS) e Oscar Vilhena Vieira (Coordenador da ONG Conectas Direitos Humanos e professor da PUC-SP). Da segunda parte, participaram: Juçara Dutra Vieira (presidente da Confederação Nacional dos Trabalhadores em Educação - CNTE e da direção do CPERS Sindicato) e Virgínia Feix (coordenadora executiva da Themis -Assessoria Jurídica e Estudos de Gênero, do RS). O Painel foi realizado na tarde do dia 24 de novembro, das 14 às 18 horas.

\section{PRIMEIRA PARTE}

\section{JOSÉ AQUINO FLORES DE CAMARGO} (AJURIS)

Os destinatários da atividade jurisdicional não têm sido ouvidos no debate sobre a reforma do Judiciário. É difícil discutir o Judiciário sem contextualizar. Muitos dos problemas do Judiciário são próprios de uma sociedade conflituosa e desigual, o que deságua em cada vez maior exigência de justiça. A AJURIS tem se dedicado ao debate sobre democratização do Judiciário e, mais recentemente, ao acesso à justiça e à efetividade das decisões judiciais.

A Reforma do Judiciário se coloca na perspectiva de implementação de um modelo que vem de fora para dentro. Seu mote de fundo é a centralização cada vez maior do poder. Está havendo cada vez mais um déficit de soberania. O mote constitucional é do Estado Democrático de Direito que colocou cláusulas de democratização na perspectiva da desconcentração do poder (divisão do poder e pacto federativo). A administração dos serviços da dívida consome cerca de $40 \%$ do orçamento público. Direitos fundamentais exigem investimentos de porte no social; o comprometimento com a dívida inviabiliza investimentos em políticas públicas. Pressão externa exige concentração do poder. A concentração tende a aumentar as injustiças e a desigualdade.

$\mathrm{Na}$ reforma da previdência duas cláusulas pétreas foram atingidas (significam "transferência de bolo" para setor privado): perdeu-se independência dos poderes; o servidor público foi reduzido em seu acesso (Contribuição certa, resultado incerto). A dignidade da velhice fica confiscada!

Superar a imprevisibilidade e a não confiabilidade são dois elementos que têm sido exigidos na reforma do judiciário. Justiça tem a função de dizer o direito via a jurisprudência. Motivo? Há lacunas e contradições no sistema legislativo. Juiz tende a agir com discricionariedade e, em suas posições, a ser político em sentido estrito. Modelo de fora para dentro traz a ideia da súmula vinculante, o que impede a oxigenação do poder judiciário.

A AJURIS é contrária ao controle externo do Judiciário. Esta proposta fere a independência. O Conselho Superior de Magistratura, tanto na França corno na Itália, amplia a influência do poder Executivo sobre o judiciário.

É contra a proposta de federalização dos crimes contra os direitos humanos, em virtude da baixa capacidade de ação da Justiça Federal, da concentração da convocação de competência no Ministério Público Federal e porque não há definição precisa do que são crimes contra os direitos humanos.

A Reforma Judiciário tem que fazer mudanças infraconstitucional para ser simples, menos onerosa e mais rápida, a exemplo dos Juizados Especiais. Há um livreto da AJURIS com centenas de propostas no campo processual. É preciso mudar a cultura dos juízes para serem mais fáceis, próximos do povo, desenvolvendo uma postura mais objetiva e direta. A democratização interna é fundamental para abrir o sistema judiciário.

\section{OSCAR VILHENA VIEIRA}

(CONECTAS: Direitos Humanos)

É de fundamental importância abrir este debate na sociedade, pois somente restringi-10 aos operadores da justiça é trabalhar com os que têm interesses diretos implicados.

Analisará a PEC 29 procurando olhar para o impacto dela sobre a questão dos direitos humanos. Debate sobre reforma do judiciário não é 
novo. O primeiro projeto é de 1989, um ano depois da nova Constituição (1988). Entende que as propostas que tramitam sobre o tema podem ser qualificadas em três categorias:

A) Democratizantes: Têm cunho democratizante parcial, exigindo construção de maior transparência no Judiciário, mas não avança no sentido da democratização do acesso (proposta de Bicudo).

B) Corporativistas: Privilegia as propostas de organização do Poder e das prerrogativas dos juízes (propostas da AMB).

C) Economicistas: Visam adequar o Judiciário ao que quer o Banco Mundial, no sentido de superar a imprevisibilidade, ampliar a concentração de poderes e de reverter um certo excesso de democracia - por exemplo, a ideia de que o juiz só aplica lei que considera justa. (proposta Aluízio Nunes Ferreira).

As três vertentes não tocam na erosão do poder da justiça no Brasil. Sistema jurídico sempre foi utilizado somente pelas elites - colonização do instrumento público por particulares. Efetivamente não trabalha a ideia da democratização da justiça. Não altera nada sobre Defensorias Públicas ou sobre Juizados Especiais. A questão do acesso à justiça está à margem da PEC 29/02.

Há uma erosão da autoridade da lei - Faoro diria que o patrimonialismo é persistente. Com o processo de urbanização, houve um crescimento da indignação com a opressão. O Direito não seria instrumento de imposição de condutas desejáveis. Exemplo dessa erosão: Brasil teve, em 2002, 46 mil homicídios. Em torno de 40 mil por ano nos últimos 10 anos, atingindo jovens, moradores de periferia ( $53 \%$ de SP e RJ), em sua maioria pardos ou negros. $\mathrm{O}$ mesmo ocorre quando o Estado ou o Poder Judiciário aparece envolvido em corrupção, na venda de sentenças - podemos falar de sistematicidade significativa da corrupção na justiça. $O$ Direito tem dificuldade de ordenar comportamentos.

O que nos faz respeitar a lei? 1) Cognitivo: é preciso saber o que é a lei e o sentido efetivo de uma ordem organizativa e de uma esfera de proteção independente das condutas individuais; 2) Utilitária e Instrumental: por um certo grau de sanção maior ou menor e por entender que descumprir pode gerar inviabilização de interesses privados; 3) Ética: por respeito aos outros, aceitamos procedimentalmente como sendo justos os instrumentos legais disponíveis.

Em sociedades cindidas, que não compreendem o outro como igual, nenhuma dessas razões funciona suficientemente. Por quê? a) Há problemas de ordem cognitiva, por falta de acesso ao conhecimento; b) O grau de sanção é distribuído de forma desigual, privilegiando os que estão em melhores condições; ademais não há sistema de constrangimento para cumprimento de interesses; c) As razões de ordem ética não tendem a ver o outro como sujeito de direitos. Este cerne gera desrespeito sistemático pelo direito e impede seu respeito de maneira razoavelmente voluntária. Os que estão abaixo do nível médio ficam opacos e invisíveis. Na média, os que conseguem burlar. Acima, os especiais e inacessíveis. O Direito poderia ser ponte de construção de igualdade, mas a PEC 29/02 não incide neste processo, sequer de forma tangencial.

Problemas de Acesso não são tocados na PEC: a) Distanciamento da justiça formal das pessoas porque é custosa e complicada. Em geral a maioria só acessa a trabalhista ou penal; b) Omissa em ampliação da defesa autônoma e não dependente: não há enfrentamento do monopólio do acesso com defesa paga - exemplo, a disputa de OAB com o modelo Pro Bono considerando que o advogado tem um papel fundamental para ampliar o acesso à justiça.

PEC também não fala nada sobre mecanismos que não sejam formais. O maior problema não é chegar à justiça e sim sair dela. Não há qualquer debate sobre processos de composição comunitária de resolução de conflitos.

O que há de bom no aspecto dos direitos humanos na PEC 29/02:

1. Resolve problema da hierarquia constitucional dos direitos humanos (Tratados e Convenções são aprovadas com quorum de emenda constitucional);

2. Jurisdição federal dos crimes contra direitos humanos: serão ordinariamente levados à Justiça Estadual, na medida em que esta seja inoperante, poderia ser guindado à Justiça Federal, cabendo ao Procurador Geral da República pedir e ao Superior Tribunal de Justiça decidir - transição mediada. A crítica é que o pedido seja 
reservado somente ao Procurador Geral, poderia ser aberto ao menos aos membros do Ministério Público ou às famílias.

3. Transparência do Poder Judiciário: O controle externo é um passo fundamental. No que está na PEC vai sentido de ampliar o controle da cúpula sobre a base. É preciso haver controle, como em qualquer poder republicano que tem que prestar contas à sociedade.

4. Novo papel para a Justiça Militar, que deixaria de julgar crimes de militares contra civis, com competência determinada pela Constituição.

\section{DEBATE}

Adriana (Adepers): Solicita opinião sobre incidência da Reforma nos Juizados Especiais, já que vem sendo feita por juízes leigos e com propostas que retiram a opção, obrigando que todas as causas com valor de até 40 salários sejam de sua competência.

Magali (Sindjus-RS): Manifesta preocupação com o problema da alteração da lei dos Juizados Especiais no RS, que tornou obrigatória a passagem de causas por eles e não alternativa. Ademais não há investimentos. Defende que o controle do Judiciário deve ser Popular, com controle social da população, com participação da sociedade civil (detalhes da proposta encontram-se em Justiça e Democracia. Caderno de Debates da Coordenação Nacional dos Trabalhadores da Justiça, Ano 1, n. 1, janeiro 2002).

Oscar (Conectas): Chamar de Tribunais Especiais já foi um avanço. Pensa que as grandes causas é que deveriam ser descoladas do judiciário, no sentido de mediações extrajudiciais (gente que tem dinheiro é que poderia fazer isso). A banalização da prestação jurisdicional para classes populares redunda em não garantir acesso à justiça. Leigos arbitrando a justiça passam a ter interesses e perde-se o componente forte que é o da imparcialidade.

Aquino (Ajuris): As deficiências no tocante aos trabalhadores são generalizados. Com relação aos Juizados, não se trata de dar uma justiça subalterna aos pobres e sim de garantir alguma justiça aos pobres. $\mathrm{Na}$ justiça comum, o tempo médio é de um ano; nos juizados especiais, é de seis meses. Se o cidadão comum for contra o Juizado Especial é negativo. $\mathrm{O}$ Juizado Especial é ágil, simples e informal, uma proposta alternativa. Parecer do juiz é que homologa a decisão do juiz leigo.
Adriana (Adepers): No Juizado Especial, não há acesso igualitário.

Carmem (Themis): É favorável ao controle popular de todos os poderes. Principal forma de controle se dá via poder de eleger, no Legislativo e Executivo. No Judiciário, não há eleição. No que é proposto pela Reforma, haveria um avanço, mas poderia gerar desigualdade de controle. É necessário pensar o controle social do Estado Democrático de Direito em sentido mais amplo.

Denise (Fundação Ford): Os casos levados aos tribunais internacionais de direitos humanos são todas por ineficiência do Poder Judiciário. Os mecanismos internacionais seriam uma forma de controle externo? Como isto entraria na ideia de controle? Como pensar o controle externo para além de uma função corregedora?

Oscar (Conectas): Há duas questões mal resolvidas: uma, do monopólio de jurisdição do juiz. Há somente controle hierárquico pelas instâncias. Modelo mais produtivo é o de competição jurisdicional modelo criado nos EUA para tratar de questões de discriminação racial. No plano dos direitos humanos, temos sucção internacional. Acha modelo de competição jurisdicional (justiça federal, justiça estadual e justiça internacional) mais produtivo. Evidente que a maior parte das questões deve ser resolvida pela justiça local. Outro aspecto é o da visibilidade. Televisão do judiciário tem ajudado nisso. É uma forma de controle. Outro é o da própria ação do ensino jurídico. Maior relação entre ensino do direito e a decisão judicial ajuda, pois intelectualidade controlaria a decisão do juiz. Conselho não é controle de jurisdição, sua função principal seria de governança judicial. Política pública de acesso à justiça é aspecto fundamental, mas precisamos uma agenda para tal. Um órgão de governança participativa seria fundamental como coordenação das Ouvidorias (não das corregedorias). Ministério Público, no entanto, não pode ser denunciado por ninguém, senão por outro igual a ele. Composição tem que ser mista e menos dos internos e nunca da cúpula sobre a base.

Aquino (Ajuris): No Tribunal de Justiça do RS, criou-se uma instância de controle da ação dos desembargadores. Qualquer ideia de controle externo seria partidarizada. Sistemas de participação direta são deficientes e muito pouco participativos. Controle externo com maioria externa significa invasão do poder político no Poder Judiciário. Acho que 
deveria haver mecanismos de participação de juízes de base no controle externo. Com relação à federalização dos crimes contra direitos humanos, ressalta que fere o princípio universal do juiz natural. Concentra poder, dando feição distorcida à jurisdição. Combate ao crime organizado exige fortalecimento da ideia de federação.

\section{SEGUNDA PARTE}

\section{JUÇARA DUTRA VIEIRA (CNTE/CPERS)}

Cumprimenta a coordenação da mesa e o público que ainda nos prestigia neste momento. Quando recebeu o convite do Dr. João Abílio, lembrou das circunstâncias em que se conheceram, nos anos 90, em Vacaria, uma época que costumava ir muito ao Fórum. Uma vez foi porque haviam entrado com uma ação protestando contra o aumento abusivo do salário dos vereadores. Numa outra ocasião, discutiu-se o problema de uma escola de Vacaria, uma das poucas escolas profissionalizantes de periferia. A Delegada de Educação promoveu mudanças nos dias letivos e no horário de inicio das aulas, dificultando a presença dos alunos, trabalhadores e no turno noturno. A insensibilidade administrativa levou o debate à Justiça. Conseguimos flexão no horário e os alunos conseguiram continuar estudando, talvez a única forma de acesso à informação e a cultura para aqueles meninos e meninas. Nas duas oportunidades, estávamos lá, uma por questão de ética e outra por uma questão de direito. Nas duas, com a legitimidade de quem estava representando todo um setor da sociedade, independentemente de estar corretos ou não.

Este debate é importante na medida em que traz diversos setores que não apenas aqueles especializados. Para os especialistas, a fala dos trabalhadores pode se tornar monótona. Mas, num país com milhões de analfabetos, a legitimação das vozes não é uma coisa pequena, não é uma coisa insignificante. Temos uma cultura da autoridade que perpassa as várias áreas do conhecimento. Por exemplo, é possível que o Machado de Assis se esqueça de uma crase, mas ele tem autoridade suficiente para que entre nas gramáticas a sua exceção passe a regra geral; no caso da saúde, temos pais e mães que conhecem profundamente seus filhos, seus sintomas, sua saúde, mas não têm a mínima legitimidade pra dar uma opinião para ajudar no diagnóstico daquele que é formado em medicina. No caso do Judiciário, nossa opinião é que este distanciamento se soma também à questão da representação do poder. Já foi dito que, com todos os limites, o Executivo e o Legislativo têm um processo periódico de afinição da cidadania, através da votação; o que não ocorre com o Judiciário. Quando o dr. Aquino falava a respeito da reforma da previdência, lembrava que a proposta teve uma simbologia muito grande, já que foi o presidente LULA com 27 governadores que a levou ao Legislativo. O Poder Executivo, com a força da federação, acabou se sobrepondo ao Legislativo. Agora, com a PEC paralela, informação que recebi há pouco da Rádio Gaúcha, podemos compreender que a reforma acabou.

Este parênteses sobre as reformas era exatamente no sentido de nós estarmos situando que em todos os poderes nós temos, em graus maiores ou menores, um certo autoritarismo de um sobre outros, seja pelos instrumentos de que eles dispõem, seja pela própria cultura que temos cultivado em nosso país.

Em relação à reforma do judiciário e ao distanciamento do Judiciário em relação ao povo. Além da alta especialização deste campo do conhecimento, o fato de que temos toda uma tradição do direito romano ainda vigorante, faz com que, em muitas circunstâncias, tenhamos que pedir tradução das expressões e dos documentos. Mesmo que seja comum que cada setor ou instituição desenvolva certos jargões e procedimentos, no caso da Justiça, estamos falando do fato de que a população realmente tem extrema dificuldade de entendimento da linguagem do discurso específico. Aliás levam a sínteses e as pessoas trabalham já a partir das sínteses, de modo que não é necessário explicar um conceito. As sínteses facilitam a vida de quem já é da área, mas dificultam a comunicação com o grande público e impedem que ele tenha acesso. Sem entender, é difícil para a população opinar sobre o judiciário.

A população visualiza o Judiciário na figura dos juízes, mas é necessário pensar no conjunto das funções que integram a prestação jurisdicional. Temos que pensar no todo. Não entender a complexidade é acabar dominado pela força da sua estrutura e pelo papel que desempenha, o que pode redundar, muitas vezes, em situações inibidoras do próprio direito. Na concepção comum de reduzir o Judiciário ao Juiz está a ideia 
que preside o sistema, levando a uma tendência de que se trata de uma operação técnica exercida por alguém que tem mérito suficiente para isso porque estudou porque se formou, porque conhece o seu ramo. Este modelo técnico esconde a ideologia da neutralidade. A neutralidade é dificilmente conseguida em ciências sociais. Ora, a Constituição não é uma peça técnica, ela representa aquilo que foi possível compor em determinado momento histórico. Um modelo que se protege na ideia de que a prestação jurisdicional é uma prestação técnica tem uma incoerência interna. Se toda prestação jurisdicional é derivada da Constituição e se esta também é política, então não há como aquela ser estritamente técnica.

É necessário nós termos uma organização (como o IAJ) que dê conta de discutir e promover o acesso à justiça, porque temos problemas na base, mas também temos problemas naqueles que são formadores de opinião e que formam uma elite mais intelectualizada ou das classes dirigentes. Vivemos um tempo de mudanças muito grandes: nas relações internacionais; as trazidas pela modernização técnica que leva à maior simultaneidade nos acontecimentos; as da força do capital, que não respeita muito as legislações e as fronteiras dos estados nacionais; entre outras. Ante esta situação, a gente deve se perguntar para que serve o direito.

A função do Judiciário deveria ser da garantia dos direitos fundamentais. Por isso trouxe aquele exemplo da educação no início da fala.Um judiciário que se assenta numa concepção técnica acaba sendo um instrumento de resolução de conflitos com base numa ordem já instituída, mas sem possibilidade de avançar a respeito desta ordem.

O controle social do Judiciário deve estar no centro do debate sobre a reforma do judiciário e aqui nós estamos tratando do controle sobre o poder, sem escamotear que os outros poderes também têm insuficiência de controle. O controle do Judiciário é essencial porque significa que estamos protegendo o que é fundamental: a soberania nacional. Controle supõe não apenas acompanhamento, exige também avaliação. Assim como o professor precisa de liberdade de expressão em sala de aula, o juiz não pode sofrer constrangimentos na sua função de analisar e julgar. Porém, assim como não aceitamos interferência na aula do professor, não podemos silenciar diante do fato de que no Brasil as crianças chegam até a 4a série sem saber ler, a escola tem que ter o controle.
Finalmente, algumas posições mais diretas. Em primeiro lugar, é correto reivindicarmos uma democracia interna no poder e na relação com a sociedade, isso significa superar a centralização autoritária da cúpula dos Tribunais. A democracia interna facilita o controle social. Não basta controlar as cúpulas se não houver também uma democracia interna. Segundo, a questão da uniformização da jurisprudência, mesmo que represente acúmulos, não dá conta de duas coisas: das situações específicas e dos direitos das minorias em situações específicas. Terceiro, ampliar as Defensorias Públicas é fundamental para o acesso à Justiça. Quarto, há necessidade de mudanças também nos ritos processuais que são protelatórios. E, por último, a superação dos entraves linguísticos: a sociedade precisa se apossar das informações e através disso possa ampliar sua capacidade de opinar.

\section{VIRGÍNIA FEIX (THEMIS)}

Este é um início de debates da sociedade civil. É fundamental que a AJURIS também puxe este debate.

A ideia da eficácia e a medida da eficácia, por si só, levam a pensar equivocadamente na reforma da estrutura do Judiciário. A questão mais importante é sobre o significado de acesso à justiça. Mais como garantia de justiça social. Está mais vinculada à ideia de implementação, mais do que de garantia. Muito além de reforma administrativa. Há instituições que funcionam no modelo pré-Constituição, exemplo a cegueira da Justiça. Há necessidade de um novo modelo de Estado, que está claramente expresso na Constituição e que vem sendo insistentemente negado.

Quando se fala do Direito é necessário distinguir três aspectos: a) Conteúdo do Direito: Legislação e interpretação da legislação; b) Estrutura do Direito: Procedimentos e organização; c) Cultura do Direito: Representações sociais e sentimentos populares sobre o direito.

Entende que o central é a mudança da cultura do direito. Isto passa pela formação. $O$ fato de que maioria das faculdades não têm cadeira de direitos humanos e de direito internacional dos direitos humanos gera uma formação deficitária. 
Há uma falência do estado liberal e uma incapacidade de reconhecimento da diversidade social e cultural. Isto está na base do debate sobre a Reforma do Judiciário, ou deveria estar.

As Promotoras Legais Populares (PLPs), experiência desenvolvida pela Themis, geram empoderamento das mulheres das classes populares, ampliando sua capacidade de acesso à Justiça. Partindo desta experiência, é necessário avançar no sentido de construir uma política pública nacional de acesso à justiça, com Agentes Comunitários de Justiça e outros mecanismos e instrumentos.

(Em conclusão houve a apresentação do Vídeo Em Frente da Lei tem um Guarda, produzido pela Themis, sobre a experiência das Promotoras Legais Populares)

\section{DEBATE}

Oscar (Conectas): Gostaria de saber da avaliação da implementação do projeto PLPs no Brasil?

Virgínia (Themis): São em torno de 30 ONGs que atuam neste projeto e formou-se uma rede para atuar. Há também proposta de diretrizes para uma proposta de política pública neste campo e está sendo viabilizada a construção de lobby para fazer uma grande Campanha por uma Política Nacional de Acesso à Justiça. Centro é a ideia de um Agente Comunitário de Acesso à Justiça, parecido com os agentes de saúde. Não seriam contratados pelos Prefeitos e sim por ONGs, enfocando visibilidade de diversos setores sociais. Próximo passo é desenhar a proposta de política pública e viabilizar a campanha, que é tarefa do grupo de trabalho formado por diversas ONGs que participam do processo.

Aquino (Ajuris): Projeto Centro de Integração da Cidadania poderia ser um modelo para proteção e ampliação do acesso à justiça e a outras políticas públicas.

Juçara (CNTE/CPERS): Têm preocupação com grupos vulneráveis e especialmente com o problema do trabalho infantil. Esta deveria ser uma preocupação que hoje está mais internacionalizada que localizada. Pesquisa na escola indicou que professores não sabiam que alunos trabalhavam. Na outra ponta, também está desamparada a velhice.
Virgínia (Themis): Igualdade entre homens e mulheres ainda é uma agenda ampla, apesar dos avanços. Ação das organizações da sociedade civil tem sido fundamental para isso e tende a ser fundamental para também enfrentar o trabalho infantil. Obrigatoriedade da notificação da violência contra a mulher foi um avanço, é preciso avançar também na proteção da infância.

João Abílio (IAJ): Problema mais grave é que a criança não tem visibilidade em nosso país, não é entendida como sujeito de direitos. Judiciário ainda trata crianças como seres incapazes. É uma questão muito grave.

Aquino (Ajuris): Há uma distância grande entre judiciário e população. Democratização exige uma nova abordagem e uma revisão da meritocracia ainda muito forte no judiciário. Este é o último poder que precisa ser democratizado. Tem receio do controle externo ser centrado no controle via partidos. Juízes têm tentado entrar no debate.

Clédis (Codene): Há 92 comunidades quilombolas no RS e 64 estão sendo mapeadas. Há uma situação de abandono e de trabalho infantil e de falta de acesso à educação. Seria muito importante que as comunidades quilombolas pudessem ter acesso à formação de agentes sociais para trabalhar com acesso à justiça. 


\section{APROFUNDANDO OS DIÁLOGOS}

O Painel foi coordenado por Vera Soares (FAEN) e contou com a participação de Maria Tereza Sadek (diretora do Centro Brasileiro de Estudos e Pesquisas Judiciais - CEBEPEJ - SP), Charles Pranke (Técnico da Associação de Apoio à Criança e ao Adolescente - AM ENCAR - RS) e de José Eduardo Martins Cardozo (deputado federal - PT-SP, presidente da Comissão Especial da Reforma do Judiciário na Câmara dos Deputados). O Painel foi realizado no dia 25 de novembro, das 9 às 12 horas.

\section{MARIA TEREZA SADEK}

\section{(CEBEPEJ)}

A exposição será dividida em duas partes. Na primeira, faremos uma reflexão a respeito das questões da Justiça e do acesso à Justiça, do ponto de vista histórico e teórico. $\mathrm{Na}$ segunda, propomos uma discussão sobre o problema do acesso à Justiça e da efetivação dos direitos no nosso país. No que se refere ao Brasil, saliento que estamos diante de problemas muito preocupantes e que, na verdade, sugerem indagações sobre temas centrais na reforma do Judiciário - efetividade da prestação jurisdicional e democratização do acesso à Justiça.

Para estimular o debate, valeria a pena desenvolver uma reflexão a respeito das ideias de justiça e de acesso à Justiça. O que é Justiça e uso da justiça, como surgem essas questões na história da humanidade? A justiça, enquanto valor, é um bem praticamente universal, sendo difícil datá-lo historicamente. Não há povos que, de uma forma ou de outra, não tenham se defrontado com uma concepção de justiça. Pode-se, pois, sustentar que, desde tempos imemoriais, sempre se elaborou uma ideia de justiça. Na sua concepção moderna, contudo, tal como entendemos hoje, a justiça e sua distribuição constituem um tema do Estado Moderno, um problema que nasce com os direitos individuais. Efetivamente, apenas quando se começou a acreditar que os direitos do homem constituíam uma qualidade intrínseca ao próprio homem e que, como tal, nada se devia à sociedade nem às autoridades constituídas, a questão da justiça começou a ser enquadrada em um outro paradigma.
Houve, então, uma mudança de qualidade nos termos da discussão. Referimo-nos precisamente ao jus naturalismo, às elaborações teóricas desenvolvidas nos séculos XVI, XVII e XVIII, quando os homens passaram a ser entendidos como sujeitos, como portadores de direitos, como entes individuais e autônomos; e a sociedade e o Estado como construções humanas.

Para os jus naturalistas, os homens passaram a ser apreendidos como criaturas que nasciam livres, como seres que nasciam com direitos. O que significava isso e quais as consequências desse suposto? Tratava-se de uma grande revolução, tanto do ponto de vista da concepção sobre o homem como sobre a sociedade e o poder. Por quê? Porque passou-se a acreditar que, se o homem nascia livre, os direitos que ele possuía eram direitos naturais, intrínsecos à sua própria natureza. Eram direitos dele, atributos seus, qualidades suas que ele não devia nem a alguma entidade sobrenatural nem mesmo às autoridades então constituídas.

Assim, a liberdade não era uma concessão ou uma característica de uma camada social ou de um estamento, mas uma característica do próprio homem. Locke, por exemplo, afirmava: "o homem define-se por sua vida, liberdade e bens”. Do ângulo teórico, tal concepção implica uma revolução radical. Anteriormente, acreditava-se que os homens nasciam predestinados ao lugar que ocupavam numa determinada sociedade. Alguns nasciam para ser servos, outros nasciam para ser senhores; o rei possuía sua posição de proeminência por uma dádiva e vontades divinas; o papa também ocupava uma posição de destaque respondendo a uma incumbência divina. Isso significa dizer que a desigualdade social - e este é o ponto central - era vista como natural. A desigualdade era natural, existia porque os homens nasciam desiguais. Não se tratava de uma vontade deles próprios, mas de uma ordem preestabelecida, contra a qual nada se poderia fazer. Com os supostos do jus naturalismo tem-se uma inversão total daquela concepção. Passa-se a acreditar exatamente no oposto. Há uma inversão nos termos da equação. Os homens são apreendidos como iguais, pois nascem iguais. Toda e qualquer desigualdade é uma desigualdade provocada pelo arranjo societal, pelo arranjo estatal, pela vida dos homens em sociedade. Tanto a sociedade como o Estado são frutos do homem e não o inverso. Dessa forma, a desigualdade deixa de ser natural e transforma-se em problema. A sociedade e o Estado são obras do homem. A sociedade e o Estado - posteriores formalmente ao indivíduo - devem respeitar os atributos individuais. 
A justiça, na sua versão moderna, e também o tema do acesso à justiça, nascem imbricados nestas concepções de indivíduo, de igualdade, de direitos individuais, de direitos iguais, de direitos de homens iguais e que tornam os homens iguais. A garantia dessa igualdade depende da Justiça, uma justiça que deve ser exercida não mais pelos particulares, mas pelo poder público. Daí a luta para se retirar dos poderes privados o direito de fazer justiça e a instituição de uma justiça controlada pelo rei. A distribuição de justiça tem que ser da responsabilidade do poder público e não do poder privado. Justiça e universalidade das leis estão, portanto, intrinsecamente ligados. Homens iguais e leis iguais. Uma lei igual para todos. Lei protetora de direitos e aplicada por uma instituição comprometida com os direitos, com a lei universal e não com os poderes privados, com os particularismos.

O acesso à justiça é uma condição imprescindível para realização dos direitos individuais. Direitos individuais que traduzem a igualdade natural. E a garantia da igualdade natural está nos tribunais. Portanto, toda e qualquer concepção de justiça, depende de acesso a tribunais. É a concepção de que aquela igualdade natural só se realiza nas sociedades concretas com a existência dos tribunais, de cortes aptas a fazer com que a lei universal seja aplicada de forma imparcial, independentemente dos atributos das partes envolvidas na disputa.

Esta primeira concepção moderna sobre a justiça, no entanto, sofre transformações - diria de monta - no decorrer dos tempos. Provavelmente, a primeira grande transformação tenha acontecido nos Estados Unidos, quando os pais fundadores da república norte-americana e autores da Constituição conceberam o Judiciário não apenas como um tribunal encarregado de garantir os direitos naturais, os direitos individuais, mas também como um poder político. Quando nos Estados Unidos se argumentava que o poder tem que ser dividido para se evitar o arbítrio, colocava-se no Judiciário uma parcela do poder político. Ou seja, o poder não concentrado, dividido entre três forças - o Executivo, o Legislativo e o Judiciário -, significa também que os direitos individuais serão garantidos por um tribunal que é ao mesmo tempo uma instituição prestadora de serviços e uma força política.

Qual é a consequência política, que se pode caracterizar como paradoxal, dessa criação do Judiciário como poder político? Com este tipo de tribunal se inibe, ou pelo menos se colocam sérias barreiras, ao poder da maioria. Ou seja, a vontade do demos não é absoluta, mas tem limites na Lei, na Constituição.

\section{Expliquemo-nos.}

Estamos habituados a falar em democracia de forma genérica, inespecifica, como se houvesse apenas uma construção política merecedora dessa designação. A rigor, isto é uma simplificação capaz de induzir, com muita frequência, a erros. Há pelo menos dois modelos muito distintos, quase opostos, de democracia. E, embora ambos sejam legitimamente dignos desta qualificação, perseguem objetivos distintos. Uma é a democracia que, por falta de melhor nome, chamaremos de "madisoniana", que é a democracia criada nos Estados Unidos da América do Norte. Este modelo de democracia é diferente de um outro que denominaremos de "majoritária".

Na concepção de democracia do tipo "madisoniana" acredita-se que se o Legislativo - lugar por excelência da representação popular - pudesse agir sem limites, alterando o tempo inteiro a realidade, ou o status quo, os direitos individuais poderiam ser ameaçados, poderiam estar correndo risco, não estariam preservados. Era necessário, portanto, que se pusesse limites, que se construíssem barreiras ao poder da maioria, ao poder da demos, ao poder do povo. Foram, assim, criados vários mecanismos para cercear este poder da maioria, entre eles: a divisão do Legislativo em duas Casas - Senado e Câmara dos Deputados; o eleitorado foi separado em vários colégios, cada um responsável pela eleição dos titulares dos diferentes postos de mando (Presidente, senadores e deputados); conferiu-se à Presidência o poder de veto; foi atribuído ao Executivo o poder de controlar o Legislativo que, por sua vez, deveria também controlar o Executivo e o Judiciário; instituiu- se o federalismo; e, talvez o mecanismo mais importante de todos para controlar o poder da maioria, conferiu-se ao poder Judiciário o poder de controle da constitucionalidade das leis e dos atos normativos.

Nesta rede de controles e contrapesos constitucionais, passou a corresponder ao Judiciário um papel de destaque: atuar como uma força de proteção das minorias e do status quo, impedindo que maiorias eventuais pudessem efetivar sua vontade, determinando quaisquer políticas públicas. Ou seja, como o demos pode optar por grandes mudanças, é necessária a existência 
de um poder que barre ou que trave essas mudanças. Em nome do quê? Dos direitos individuais, das liberdades individuais e da proteção das minorias.

De forma resumida é, pois, possível dizer que o Judiciário nasce no presidencialismo como um poder político, com a função básica de exercer o controle da constitucional idade das leis e dos atos normativos oriundos do Executivo e/ou do Legislativo. No sistema presidencialista, no modelo de democracia adotado no sistema presidencialista, o Judiciário tem claramente duas faces. Uma face é política por excelência - o Judiciário é um poder político, um Poder de Estado. A outra face é caracterizada como de prestação de serviços; de garantia de que os direitos individuais serão de fato efetivados; e que os conflitos poderão ser resolvidos por uma entidade pública, neutra, capaz de arbitrar disputas.

No outro modelo de democracia - "democracia majoritária" -, não se trata fundamentalmente de evitar a acumulação de todos os poderes nas mesmas mãos e nem mesmo de neutralizar as chances de tirania das maiorias sobre as minorias. A preocupação básica é distinta: conferir soberania absoluta para a maioria. O que se assiste na Europa, grosso modo, berço do sistema parlamentarista (posterior historicamente ao presidencialismo) é a ocorrência de todo um processo cuja finalidade última é retirar o poder das mãos do monarca e transferir esse poder para o demos, para o Parlamento. $\mathrm{O}$ Parlamento transforma-se, gradualmente, de Casa Consultiva em Casa Deliberativa. Ou seja, o Parlamento constitui-se em sede do poder, em local no qual o poder soberano - o povo - tem seus representantes.

Dessa forma, o sistema parlamentarista resulta da transferência do poder do monarca absolutista para o monarca constitucional, desempenhando este um papel de representante do Estado. A chefia do governo cabe a um primeiro ministro, ungido ao poder pelo Parlamento - a sede, por excelência do poder. Neste modelo, não há nada que o povo esteja impedido de fazer. Daí a famosa expressão inglesa: "o parlamento tudo pode". Não há nenhum órgão, nenhuma instituição que imponha limites aos poderes do Parlamento. O demos, o povo, representado no Parlamento é soberano. Nesta construção institucional, o Judiciário não possui uma face política. Há os tribunais constitucionais, encarregados de examinar a constitucionalidade das leis e atos normativos. Esses tribunais, contudo, não pertencem à estrutura do Judiciário. Não estão no ápice da estrutura do Judiciário. São tribunais políticos propriamente ditos, formados politicamente. Embora haja grandes variações de país parlamentarista para país parlamentarista, em todos eles os tribunais ou as cortes constitucionais não têm ligação com o Judiciário. Em alguns, as cadeiras são ocupadas por indicação do Executivo, do Legislativo e do próprio Judiciário; em outros, só a maioria parlamentar indica seus integrantes; em alguns, ainda, não cabe o controle jurisdicional das leis, pois isto significaria a superposição de uma instituição acima da vontade popular, que é exercida pelo Parlamento. Mas, em todos eles, independentemente da variação nos critérios para a composição, existe mandato, não cabendo, como no caso da organização judicial, o princípio da vitaliciedade ou da aposentadoria por idade.

A grosso modo pode-se, portanto, dizer que o Judiciário, nas democracias que se organizam politicamente de forma parlamentarista, não tem uma face política. É fundamentalmente uma instituição prestadora de serviços.

Caberia, nesse momento, um parênteses para fazer uma referência à controvertida questão do controle externo do Judiciário. Esse problema é necessariamente distinto quando se considera o Judiciário como um poder como no caso presidencialista, e quando se tem um Judiciário apenas encarregado da prestação jurisdicional. Ou seja, mecanismos adequados ao Judiciário em um sistema parlamentarista podem ser inteiramente impróprios no sistema presidencialista. Isto não significa dizer que o Judiciário poder político não deva ser objeto de controle. É um principio básico da vida republicana que todas as instituições devem prestar contas de suas atividades. E nada isenta o Judiciário desta obrigação.

Os dois modelos de democracia, com dois tipos diferentes de Judiciário, provocam reflexos na questão relativa ao acesso à Justiça. Assim, convém sempre se perguntar: de que acesso estamos falando? Em qual situação concreta, em qual situação histórica, a qual modelo institucional estamos fazendo referência quando perguntamos sobre o acesso à Justiça? Um tipo de acesso à Justiça é aquele que se dá quando o Judiciário tem uma face predominantemente de instituição prestadora de serviços e outro tipo de acesso à Justiça se verifica quando o Judiciário tem uma face dupla, de um lado a face política e de outro a face de prestação de serviços. Ou seja, quando temos um sistema presidencialista, como de fato temos no Brasil, acesso à Justiça significa muitas coisas ao mesmo tempo. Significa, por exemplo, a garantia de direitos, inclusive daqueles direitos que podem estar ameaçados por decisões do Executivo e por decisões do 
Legislativo. Há o exercício do controle da constitucionalidade para garantir a adequação das políticas públicas ao texto constitucional.

Parece claro que o modelo de Judiciário que mais interfere na governabilidade é aquele do Judiciário com uma face política, ou do Judiciário poder político, típico do presidencialismo. Este Judiciário constituise em mais um ator político, uma força que se tem que levar em consideração quando se toma qualquer decisão, seja ela de que natureza for, da mais simples política pública até questões de natureza legal, constitucional.

Outra questão relevante refere-se ao fato de que, a despeito das singularidades próprias dos modelos institucionais presidencialista e parlamentarista, o Judiciário tem se transformado numa instituição muito mais ativa do que era no passado, em toda e qualquer sociedade, mesmo nas parlamentaristas. Mesmo no parlamentarismo mais puro, que é o modelo inglês, constata-se que muitas das políticas públicas implementadas num governo conservador, como foi o de Margaret Thatcher, tiveram a participação ativa do Judiciário. É um outro problema discutir como é formado o Judiciário inglês, não por carreira, diferentemente do caso francês, este sim, muito mais próximo do nosso modelo. O que importa salientar é a ocorrência de um ativismo judicial mesmo em sistemas parlamentares de governo.

Saliente-se, pois, que, apesar da diferença radical entre o presidencialismo e o parlamentarismo, existe um ativismo judicial, estreitamente relacionado a uma mudança na concepção dos direitos. Que mudança é essa? Dizíamos que os direitos individuais são responsáveis pela criação dos tribunais, enquanto garantidores da efetivação dos direitos individuais. No final do século XIX e no século XX, no entanto, surgiram os direitos sociais. Esses direitos, do ponto de vista formal, implicam uma fantástica transformação conceituai. É a ideia de que o direito deve ser desigual para pessoas que são desiguais. O núcleo da concepção dos direitos individuais é a proposição de que a lei é universal, igual para todos e que deve ser respeitada, independentemente, dos traços concretos e substantivos dos indivíduos. Ou seja, não importa se a pessoa é rica ou pobre, culta ou analfabeta, homem ou mulher, criança ou adulto, a lei é idêntica para todos; possui validade universal. Esta lei tem que ser respeitada, cumprida, ela é a garantia por excelência dos direitos civis.
Com o advento dos direitos sociais, incorpora-se uma outra concepção de lei. Há uma lei que não é idêntica para todos. Os desiguais são sujeitos a uma lei que leva em conta essa condição. Não se trata mais de uma lei formal igual, mas de uma lei substantiva desigual. O objetivo é diminuir ou atenuar os efeitos da desigualdade existente no mundo real. Ou seja, a distância, a disparidade existente entre os homens é concebida como algo que deve ser remediado, cabendo ao Estado atuar para superar ou atenuar as carências individuais e sociais. A desigualdade não é mais vista como natural, ou como o resultado das forças invisíveis do mercado, contra o quê nada poderia ser feito, sob o risco de se ferir o princípio da liberdade. Com os direitos sociais, passa-se a acreditar que aquelas desigualdades, quando acentuadas, são insuportáveis. Não são desigualdades que a sociedade deve continuar aceitando. Há que se criar políticas públicas que implementem a aproximação entre os mais e os menos ricos, entre os mais e os menos escolarizados, entre as minorias e as maiorias. A aproximação, ou melhor, a diminuição das consequências decorrentes das distancias sociais são os objetivos maiores das políticas públicas. Assim, quando se proclama que todos têm direito à educação, passa a caber ao Estado a oferta desse serviço, porque se o mercado fosse atuar por si mesmo, a educação não seria universal. Tem-se que criar políticas públicas que favoreçam a educação daqueles que não têm acesso às escolas. Dessa forma, as políticas públicas aproximam os extremos ou ao menos neutralizam os efeitos mais perversos da desigualdade.

Pode-se, então, sustentar que as políticas públicas ligadas aos direitos sociais são políticas que são feitas tendo em vista a desigualdade real. Ou seja, reconhece-se a desigualdade existente na sociedade e busca-se meios para atenuá-la. Assim, criam-se as defensorias públicas para os que não podem arcar com as despesas de um advogado particular; o SUS para que todos tenham direito à saúde, para que aqueles que não podem pagar médico possam ter acesso à saúde; e daí por diante.

Com o advento dos direitos sociais, tem-se uma mudança profunda na concepção sobre o papel do Poder Judiciário. Porque passa a caber ao Judiciário garantir que estes direitos também sejam respeitados; como estes são direitos para desiguais, propicia-se um ativismo judicial, independentemente do modelo institucional ser parlamentarista ou 
presidencialista. Certamente este traço é mais acentuado no presidencialismo e, mais ainda, quando se tem uma Constituição detalhista.

Nos Estados Unidos, assiste-se a um ativismo judicial desde a sua formação como nação independente. Tanto que, quando Tocqueville foi da França para os Estados Unidos, constatou que não havia nada que acontecesse naquele país que não se invocasse a autoridade de um juiz. $\mathrm{O}$ juiz, dizia ele na obra Democracia na América, é uma das forças políticas mais importantes da sociedade norte-americana. Tocqueville foi o primeiro grande intelectual a percebera influência do Judiciário e de seus integrantes no cotidiano das sociedades modernas. Muito provavelmente, o fato de ter vindo da Europa acentuava sua surpresa. Na Europa da primeira metade do século XIX, o juiz não gozava de tão ampla margem de atuação.

A observação de Tocqueville torna-se uma realidade que vai ganhando espaço e proeminência em todas as sociedades contemporâneas. De fato, hoje, quer na Inglaterra, quer na Alemanha parlamentarista, quer na França semipresidencialista, não há decisão política, não há implementação de direitos sociais que não passem pelo crivo do Judiciário.

Retomemos a questão da Constituição. A força do Judiciário nos Estados Unidos deve-se sobretudo ao sistema presidencialista, ao fato do Judiciário ser um poder com a atribuição de exercer o controle da constitucionalidade. Esta força, entretanto, depende em boa medida da vontade política dos membros do Judiciário. Cresce a potencialidade de atuação do Judiciário em um sistema político regido por uma Constituição detalhista. Assim, tem- se uma segunda subdivisão. Há tipos distintos de presidencialismo: os que possuem uma Constituição genérica e os que são amparados por uma Constituição detalhista. Desta forma, além do fato de ser presidencialista, quando há uma Constituição que desce a detalhes e que chega a ser acusada inclusive de fazer políticas públicas, de ser pragmática, a presença do Judiciário é ainda mais marcante. Em decorrência, ainda que não tivéssemos muitas informações sobre o Brasil, ainda que pouco soubéssemos sobre os Estados Unidos, bastaria o exame das respectivas constituições para poder inferir sobre a potencialidade de atuação do Judiciário. A probabilidade de atuação do Judiciário no caso em que há uma Constituição detalhista é muito maior do que quando esta Constituição é genérica.
Pode-se, então, sustentar a tese de que a participação ativa do Judiciário será potencialmente maior quando se tem uma democracia, num sistema presidencialista, regida por uma Constituição detalhista. Somando-se a essas variáveis a formalização dos direitos sociais, tem-se a constituição do Judiciário como um ator de primeira grandeza. Isso significa dizer também que o Judiciário passa a ter uma responsabilidade muito grande. À extensão do papel corresponde o crescimento de responsabilidade.

Diante deste quadro geral, formado a partir de pinceladas tão rápidas, como examinar o Brasil? Do ponto de vista do desenho institucional, tudo indica que, no caso brasileiro, quando se fala de acesso à Justiça há referências a uma situação em que o grau de participação e responsabilidade do Judiciário é dos mais altos. Ou seja, do ponto de vista de modelo formal - presidencialismo, Constituição detalhista, presença de direitos sociais -, tem-se um quadro muito propício à participação ativa do Judiciário.

Caberia perguntar em que medida isso vem de fato acontecendo? O exame de alguns dados sugerem uma indagação que, para mim pelo menos, é perturbadora. E perturbadora num grau elevado. Faço um convite para que se olhemos os dados relativos ao Poder Judiciário, mais precisamente os referentes à Justiça Comum, encontrados no site do Supremo Tribunal Federal, Banco Nacional de Dados do Poder Judiciário. A princípio, seria no Juízo Comum, que também inclui os juizados especiais, que as demandas por Justiça apareceriam. Os números são sempre espetaculares e grandiosos - milhões de processos. Vamos para os anos mais recentes. Em 1996 houve um ingresso de 5 milhões e 800 mil processos; em 1997, 6 milhões e 900; em 1998, 7 milhões e 700; em 1999, 8 milhões; em 2000, 9 milhões; em 2001, 9 milhões e 489.

Chama atenção, em primeiro lugar, a grandiosidade dos números e também o fato de apresentarem uma curva sempre ascendente. Se considerarmos o ano de 2000, quando foi feito o censo populacional pelo IBGE, chegaremos a relações, no mínimo, intrigantes. De fato, tem-se um processo para cada 18 habitantes do Brasil. No Rio Grande do Sul essa proporção é de um processo para cada dez habitantes. A pior relação dentre os Estados da Federação está na Bahia, onde temos um processo para cada 947 habitantes. Fiquemos com a média nacional: um processo para cada 18 habitantes. Vamos tentar entender essa média. 
Caso se tratasse de um país imaginário, poderíamos levantar algumas suposições. Estamos diante de uma sociedade mobilizada, sabedora dos seus direitos e que sabe aonde ingressar quando tem os seus direitos ameaçados. Haveria, por outro lado, uma instituição pública, o Poder Judiciário, que, a despeito de existir sempre uma defasagem entre o número de processos distribuídos e julgados, vem respondendo adequadamente a este tipo de demanda. Afinal, os julgados estão também sempre na casa dos milhões. Sabe-se, contudo, que esta suposição não resistiria ao menor choque com a realidade.

Sublinhe-se que, em nenhum país do mundo se encontra esta relação: um processo para cada 18 habitantes. Esta proporção significaria dizer que há um grau de conflito absolutamente insuportável na sociedade. Nem a justiça criminal norte-americana - conhecida pela grandeza de seus números - tem este índice. Nos Estados Unidos, só para que se tenha uma ideia, um em cada 36 habitantes tem um processo criminal.

Continuando a especulação para o exame dos dados relativos à sociedade brasileira, veremos que, do ponto de vista abstrato, temos uma situação que favorece o surgimento de litígios, a explosão de conflitos. Todas os estudos indicam que, quando se tem um crescimento populacional muito acelerado, cria-se um quadro propício à explosão de conflitos. Os modos de vida são rapidamente alterados, as cidades se tornam inchadas, não se consegue providenciar serviços públicos para todo mundo, as relações pessoais são substituídas pela impessoalidade, havendo alta probabilidade de aumento no grau de conflitos. Deste ângulo, o Brasil apresentaria, de fato, um conjunto de fatores favoráveis ao aumento dos conflitos. Partimos de 41 milhões de habitantes em 1940 e atingimos mais de quatro vezes mais em 2000, com 169,8 milhões. Nos Estados Unidos, por exemplo, esse crescimento ocorreu em 150 anos, enquanto entre nós deu-se num espaço de tempo de apenas 30 anos. A velocidade da mudança faz muita diferença. Por outro lado, no caso brasileiro, houve uma intensa concentração nos centros urbanos. A população brasileira urbana pulou de $31 \%$ para $78 \%$ nos anos 1990 . E não estamos nos referindo a qualquer tipo de cidade, mas a cidades sem as mínimas condições de vida, sem infraestrutura, com a população morando em locais que não oferecem as condições mínimas, adequadas, ou civilizadas, se quiserem, de vida. Ademais, temos um setor de serviços inchado; uma queda acentuada na mão de obra dedicada à agricultura que passa de $67 \%$ para $25 \%$ e um crescimento mais lento no setor da indústria.

Esses dados justificariam aqueles conflitos ou, melhor dizendo, o número extraordinário de processos entrados na Justiça? Poder-se-ia, legitimamente, supor que é altamente conflituosa uma sociedade que cresce rapidamente e, mais do que isso, cresce em áreas urbanas, perdendo habitantes nas áreas rurais, alterando drasticamente a distribuição de sua população economicamente ativa. Uma sociedade com tais características é uma sociedade propícia à explosão de conflitos. O exame da distribuição de renda acentua drasticamente aquela probabilidade. Trata-se de uma situação de quase absoluta iniquidade. É uma das distribuições de renda mais desiguais do mundo. Bastaria dizer que os $20 \%$ mais pobres ficam com apenas $2 \%$ da renda, enquanto que os $\left.10^{`}\right) / 0$ mais ricos têm praticamente a metade da riqueza produzida no pais. O grau de desigualdade é muito acentuado. Os $20 \%$ mais ricos ficam com mais do que $60 \%$ da renda, enquanto os $50 \%$ mais pobres pouco ultrapassam os $10 \%$. Em termos comparativos, a situação do Brasil é muito desvantajosa. O grau de desigualdade entre nós é muito mais acentuado do que nos demais países da América Latina: os $10 \%$ mais ricos no Brasil ficam com $47 \%$ da renda, enquanto a concentração de riqueza é significativamente mais baixa na Argentina, na Bolívia, no Chile, na Costa Rica.

Considerando a escolaridade, portanto, um item fundamental no conjunto dos direitos sociais, percebe-se que as políticas públicas, que seriam encarregadas de corrigir aquelas desigualdades, não têm atuado de forma satisfatória. É como se disséssemos: a desigualdade de renda deveria ser atenuada com políticas eficazes na área da educação, capazes de compensar a diferença de poder econômico. Vejamos o que se passa com a escolaridade dos mais pobres. Enquanto na Argentina os mais pobres ficam, em média, sete anos na escola, no Brasil ficam apenas 1,98. Na América Latina, nossa média é das mais baixas, com a única exceção de El Salvador.

Retomemos agora os dados referentes aos números de processos e de habitantes, especialmente a proporção que indica que no Brasil há um processo distribuído para cada 18 habitantes. Seria possível afirmar que a situação social, a situação econômica, a situação da distribuição da renda no Brasil, a ausência de políticas públicas eficazes, gerariam um potencial de conflito muito grande. No entanto, embora pouco se conheça sobre o 
Judiciário, sabe-se que não se trata de uma instituição utilizada por amplos setores da população. O Judiciário é um poder desconhecido, não apenas pela sociedade, mas também por parte de seus próprios integrantes. Não se conhece o Judiciário porque não há dados, os dados são globais, os dados são incompletos. Face à precariedade de informações, todo e qualquer diagnóstico é muito difícil de ser feito. Consequentemente, devido à falta de conhecimento do Judiciário, tem-se que tatear para chegar a algumas respostas. Com essa intenção - de apenas tatear-começo pelo dado mais impressionista que existe, que são as pesquisas de opinião pública. Em média, segundo essas pesquisas, $70 \%$ da população não acredita no Judiciário. Após o Governo do Presidente Lula, este índice cresceu, quer por ter havido uma política deliberada nessa direção, quer pela maior exposição dos problemas relacionados à justiça. Salientaria três dados que contribuíram para acentuar a imagem negativa do Judiciário:

1. A reforma da Previdência. Na discussão sobre a reforma da Previdência, os magistrados apareceram como um grupo privilegiado na sociedade brasileira. Privilegiado e desejoso de manter privilégios, em uma sociedade pobre. Ademais, foram feitas generalizações a partir de situações que não são típicas. Ou seja, a sociedade brasileira acreditou ou foi levada a acreditar que os juízes, os desembargadores do Maranhão, com salários muito altos e nenhum compromisso com a vida republicana, representavam a média dos magistrados no Brasil.

2. Em segundo lugar, o Presidente Lula contribuiu, quer intencionalmente, quer não, para esta imagem negativa. Ele acusou: "o Judiciário é uma caixa- preta". De meu ponto de vista a imagem é ruim. O que significa caixa-preta? Trata-se do recipiente que contem as informações mais preciosas, capazes de indicar o funcionamento e onde é que a máquina falhou. Ou seja, é como se tivéssemos um mecanismo apto a revelar as questões mais fundamentais, a estrutura, a base de funcionamento. Esta imagem é absolutamente falsa quando aplicada ao Judiciário. A rigor, ninguém conhece o Judiciário. Os próprios magistrados não conhecem o Judiciário. Não há dados específicos. Há números globais que dizem alguma coisa, mas dizem muito pouco. Desse ponto de vista não há caixa-preta no Judiciário. Eu diria que o Judiciário é mais propriamente uma instituição anacrônica do que uma caixa preta, com segredos guardados a sete chaves. A despeito disso, a imagem que o Presidente utilizou foi simbolicamente muito negativa para a instituição e muito ao agrado de largos setores da população e dos meios de comunicação.

3. O Ministro da Justiça assim que assumiu o cargo disse: "esse projeto de reforma do Judiciário que aí está não serve para nada, nós temos que começar do zero". De fato, o projeto que está aí não vai resolver a crise da Justiça. É um projeto pouco articulado, que esteve em discussão na Câmara por mais de 12 anos, com três relatores que apresentaram textos completamente diferentes entre si. Com sua ida para o Senado, sofreu modificações que acabaram por torná-lo um todo disforme. Por outro lado, o ministro privilegiou uma solução para a crise do Judiciário: o controle externo. A proposta de controle externo para a população em geral, que não conhece o Judiciário, que não conhece o modelo institucional, soa de forma muito positiva. Para a população, o juiz é um servidor público com muito poder e sem nenhum tipo de controle; é irresponsável; e o Judiciário é visto como uma instituição pública com muito dinheiro e que presta um serviço considerado péssimo. Ninguém discute que foram processados no Judiciário milhões de processos, mas a demora, o excesso de formalismos. Em poucas palavras, a imagem pública do Judiciário é muito negativa e eu sustento a hipótese, sujeita à confirmação, de que ela piorou neste ano.

A crise do Judiciário é reconhecida pelos seus próprios integrantes. Em várias pesquisas que pude dirigir no Idesp, há o reconhecimento de que a situação do Judiciário é problemática. $22 \%$ dos integrantes do Poder Judiciário concordam totalmente com a existência de uma crise. É um índice bastante relevante, embora menor do que o encontrado junto aos membros do Ministério Público dos Estados e do Ministério Público Federal. No entanto, uma coisa é este sentimento difuso de que existe uma crise, outra muito diferente é a capacidade de fazer um diagnóstico preciso do Poder Judiciário. E para este diagnóstico não bastam modelos teóricos, não basta uma concepção abstrata a respeito do Poder Judiciário. É imprescindível o conhecimento do Poder Judiciário, para reconhecer seus pontos positivos, seus pontos negativos.

De meu ponto de vista, o problema central do Judiciário brasileiro não é a falta de acesso. Sustento, ao contrário, que existe acesso demais, 
acesso exagerado, porta aberta demais para um tipo de litigante. Simultaneamente, há porta fechada, ausência de acesso, barreira para a maior parte dos cidadãos. Então, quando falamos em acesso à Justiça, temos o dever, como estudiosos do Poder Judiciário ou como operadores do Direito, de discutir de que acesso se trata. Temos uma legislação que facilita, que propicia que um tipo de litigante fique no Judiciário por muito tempo e saiba tirar vantagens disso. Para confirmar essa minha hipótese, recorro a uma pesquisa feita no Idesp junto a empresários brasileiros. Entrevistamos um grupo expressivo de empresários para saber a avaliação desse setor da elite nacional sobre o Judiciário. A falta de agilidade foi a maior crítica que os empresários dirigiram ao Judiciário no Brasil. No que se refere ao atributo de imparcialidade, a avaliação variou de acordo com o ramo do Judiciário em questão. A Justiça do Trabalho foi a que recebeu a pior avaliação nesse quesito: $44 \%$ julgaram como ruim e $22 \%$ como péssima. As demais Justiças foram vistas de modo menos negativo. $\mathrm{O}$ desempenho da Justiça Estadual recebeu uma avaliação muito crítica; a melhor avaliação foi atribuída ao Supremo Tribunal Federal. Embora os empresários tenham avaliado de forma muito negativa a agilidade, quando se pergunta: "o senhor acha que a Justiça é muito lenta, ela é morosa, mas isso é ruim para as empresas em geral?" A falta de agilidade aparece como benéfica na questão trabalhista para $23 \%$, na tributária para $14 \%$. É importante salientar que um percentual significativo de empresários reconhece que o fato da Justiça ser lenta traz benefícios. Esses benefícios eram maiores quando vivíamos num período com altas taxas de inflação, já que naquelas condições era mais vantajoso não pagar, não saldar a dívida, uma vez que qualquer aplicação financeira traria mais benefícios do que cumprir com as obrigações. Observe-se que um significativo percentual de entrevistados - 59\% - reconheceu que os benefícios de se recorrer à Justiça superam os custos.

Esses percentuais nos ensinam que devemos esclarecer quem são os usuários da Justiça. Habitualmente afirma-se que o poder público, os entes estatais, as entidades públicas, em geral, os empresários, são os principais usuários do Judiciário. Seria necessário examinar a veracidade dessa assertiva e apreender como se dá a balança entre custos e benefícios na avaliação desses grupos. Ou seja, quando se usa a justiça estatal, quando se abusa da justiça estatal e quando se opta por outras formas de solução de conflitos, como a mediação, a conciliação e a arbitragem.
Só com essas informações poderemos fazer um diagnóstico mais adequado sobre a questão do acesso à justiça. A ausência desse diagnóstico não nos impede, entretanto, de sustentar que, nas condições presentes, os dados sugerem que há um paradoxo: porta aberta demais e porta fechada. Não há como negar a existência de processos em excesso nesse país, são milhões de processos - oito milhões de processos julgados em 2001; 9 milhões e 500 mil distribuídos em 2001. A leitura ingênua desses números levaria à conclusão de que há acesso à Justiça. No entanto, basta conhecer um pouco a realidade brasileira para saber que é imprescindível qualificar este acesso e não se deixar seduzir pela quantidade.

Uma reforma do Judiciário capaz de provocar efeitos positivos na prestação jurisdicional e na democratização do acesso à justiça terá que lidar com o problema de qualificar o litigante, impedindo, ao máximo, o litigante de má-fé, ou litigante que sabe extrair benefícios das atuais características do Poder Judiciário. Deste ponto de vista, significa fechar algumas portas e construir outras portas, portas novas. Só assim, os integrantes do Poder Judiciário, funcionários públicos, pagos com o dinheiro do contribuinte, pelo povo em geral, estará prestando um serviço que corresponderá, de fato, às atribuições que lhe foram dadas pela Constituição, deixando de trabalhar para um setor muito pequeno da sociedade. Nas condições atuais é como se os magistrados, os integrantes do Ministério Público, pagos pela sociedade como um todo, estivessem prestando serviço para um setor muito restrito da sociedade.

No que se refere à ampliação do acesso à justiça, a mais importante reforma do Judiciário, de meu ponto de vista, ocorreu antes da redemocratização do país, com a criação dos Juizados Especiais, então denominados de pequenas causas. Esses tribunais não tinham por finalidade resolver a crise do Judiciário, mas democratizar o acesso. O espírito da lei era abrir portas, concretizar o princípio segundo o qual a Justiça tinha que ser democratizada, atraindo para a Justiça Estatal indivíduos que nunca puderam recorrer ao Judiciário. Nessa concepção, a celeridade era vista como fundamental, assim com a quebra de certos formalismos, a não necessidade de se ter advogados.

A imagem da Justiça para os setores excluídos é de uma série de portas. Abre-se uma, julgando-se que se entrou, mas depois vem outra e mais outra... E como se se abrisse uma série de portas e nunca se entrasse. 
As dificuldades são de distintas naturezas: para começar, entender uma linguagem em tudo distante do cotidiano. Em pesquisa feita recentemente no Estado de São Paulo pelo CEBEPEJ sobre os juizados especiais, encontramos cidadãos perguntando: "Mas aí o que aconteceu? Eu ganhei ou perdi?". Ou seja, o cidadão não é sequer capaz de entender se o resultado lhe foi ou não favorável. Trata-se, sem dúvida, de um vício de linguagem. Inadmissível, se o objetivo é aproximar o cidadão da justiça. Nesta mesma pesquisa sobre os Juizados Especiais cíveis no Estado no Estado de São Paulo, pudemos constatar que essas cortes de justiça estão muito distantes dos princípios que orientaram a sua criação. Assim, muitos conciliadores não conciliam, não têm preparo para exercer uma atividade vital nos juizados. Em muitos locais, a presença de conciliadores transformou-se em mera formalidade. Por outro lado, a pauta dos juizados especiais hoje chega a ser mais carregada do que a do juízo comum. Os juizados especiais estão sendo usados, sobretudo, pelas microempresas e pela classe média, enquanto a ideia original que era fazer com que as portas fossem abertas para o cidadão comum. A presença de advogado tornou-se, na prática, obrigatória. A ausência de juízes exclusivos talvez seja o maior dentre os problemas. Isso significa que a nova mentalidade, uma consequência importantíssima dos juizados especiais, não vem sendo obtida. Por quê? $\mathrm{O}$ juiz sai do juízo comum, marcado por todo aquele palavreado e formalismo e dirige-se para o Juizado Especial. Ora, não se muda o palavreado e a postura como se troca de roupa. O palavreado inteligível para o cidadão comum é uma das faces da ausência de formalismos, do desenvolvimento de uma cultura não voltada para a sentença, mas para o acordo.

Certamente, não se podem fazer generalizações. O Brasil é um país muito diferenciado e essas diferenças aparecem também no Poder Judiciário. É sabido que em muitos locais desenvolvem-se experiências notáveis de acesso à justiça.

Para terminar, diria que a real ampliação do acesso à justiça provocaria efeitos de monta na efetividade dos direitos da cidadania e seria capaz de pavimentar um novo caminho, no qual o apreço da população pelo Judiciário poderá germinar e se desenvolver.

\section{CHARLES ROBERTO PRANKE (AMENCAR)}

Questão de fundo é que judiciário queremos e, especialmente, para quem ele existe. Judiciário é um ator político. É neutro ou posicionado? Se é posicionado, a favor de quem atua.

Respondida esta questão é que poderemos determinar o que devemos e precisamos fazer para avançar na transformação do Judiciário.

Outra questão de fundo é a da que justiça queremos. Como instituição social é justificável a necessidade de controle público. Ademais precisamos trabalhar no sentido de que esse poder seja o mais popular possível.

Nos julgamentos, fica-se normalmente na superficialidade e nas consequências, sem ir a fundo nas causas, o que exigiria um conjunto de elementos analíticos oriundos das diversas ciências humanas, em perspectiva interdisciplinar, o que tem consequências sobre a organização e o pessoal do judiciário.

Relação entre ação da justiça e as políticas públicas. Será que há interesse em uma justiça que efetivamente obrigue o Estado na efetivação de Direitos. A justiça tem um papel de garantir os mínimos sociais.

Considera fundamental que a ampliação do debate seja feita.

\section{JOSÉ EDUARDO MARTINS CARDOZO}

(Deputado Federal PT-SP)

Parte do pressuposto da importância e relevância da Reforma do Judiciário e entende que ela passa pelos seguintes aspectos:

a) Por mudanças constitucionais: há várias propostas (Relatório Zulaiê com relatório de Cabral aguardando três anos de aprovação). Mais provável é que Senado fatie e aprove o que há de consenso.

b) Reforma da legislação infraconstitucional: discussão do Estatuto da Magistratura e legislação processual. O Estatuto da Magistratura tramita há mais de 12 anos, sendo de iniciativa do Supremo

Tribunal Federal (STF). Quando a Comissão estava discutindo o tema, o STF, a pedido da Associação dos Magistrados Brasileiros (AMB), 
retirou o projeto com argumento de que seriam necessárias atualizações que muito bem poderiam ser feitas no processo legislativo - e ficou de reapresentá-lo em trinta dias.

c) Gestão Administrativa: Particularmente neste ponto está em debate a informatização do poder judiciário, que é absolutamente importante.

Propostas defendidas pelo PT:

1. Controle externo: é favorável ao texto aprovado pela Câmara, acrescentando impedimento de que Deputados e Senadores e exparlamentares venham a integrá-lo. Defende instalação de Ouvidorias.

2. Sobre a Súmula Vinculante: é muito ruim pois, mesmo que agilizasse o sistema, inviabilizaria sua oxigenação-direito na sua interpretação não é neutro - e paralisaria o sistema com um minilegislativo e sem soberania popular. Alternativa é Súmula Impeditiva de Recursos: quando a decisão fosse na mesma linha da súmula existente aí não haveria recursos; quando fosse diferente da súmula haveria recurso. Sistema de recursos para ganhar tempo é inaceitável.

3. Orçamento Participativo no Poder Judiciário. Tem poucos recursos, mas quem decide é a cúpula e com situações anacrônicas no destino das verbas. As decisões têm que ser tomadas por todos os magistrados, com discussão transparente.

4. Combate ao nepotismo. Fixar explicitamente o impedimento de nomeação como troca de famílias (permuta de parentes).

5. Federalização dos crimes contra direitos humanos. Mas é necessário definir claramente quais são estes crimes.

6. Órgãos especiais dos tribunais: que tenham $50 \%$ de membros eleitos, equilibrando eleitos com a fórmula da antiguidade.

7. Questões polêmicas:
8. Eleição para cargos de direção dos tribunais, com limitação que impeça benesses indevidas e cooptação vil no processo eleitoral interno.

9. Transformar o STF em tribunal constitucional: Este órgão tem sido amesquinhado por absorver processos que efetivamente não têm sentido de estar lá. Cabe-lhe debater as grandes questões constitucionais.

10. Ademais: não é ideia defender novos Códigos. Mas é necessário intervir pontualmente no sistema processual e recursal

Finalmente, é fundamental que a sociedade esteja no debate, já que há um corporativismo de todos os agentes do sistema judiciário. E preciso organizar a sociedade para que possa incidir, para que o debate não continue uma questão esquizofrênica: todos querem, mas ninguém faz.

\section{DEBATE}

Vânia Matos (Juíza do Trabalho): Justiça do Trabalho tem uma posição em geral diferente do restante do Judiciário. Democratização do judiciário: concorda com a necessidade de maior transparência. Passa pela eleição direta dos presidentes de tribunais, a fim de superar a composição dos grupos em disputa para a direção dos tribunais. Necessário ampliar o compromisso com metas e prestação de contas, superando a falta de cobrança. Processo sumaríssimo, introduzida em 2000, é retorno de mais de 60 anos.

Sadek (CEBEPEJ): Na entrevista que deu em 10/11/03 a Folha de São Paulo, quis passar a ideia de que juiz trabalha muito. A pergunta é como, por que e para que. Há uma falta de racionalidade que faz com que o trabalho pareça improdutivo. A primeira instância está perdendo importância, pois se sabe que não é definitiva. Em geral, as sentenças não são bem qualificadas da parte da "banda podre" e a "banda crítica" pede incentivos. Disputas dos cargos dirigentes precisa ser confrontada em disputa de programa de ideias. Sem isto, gera-se uma instituição aristocrática no que isso tem de pior. Judiciário cresceu, mas é mais um inchaço, já que o sistema processual desvaloriza a primeira instância. Todo servidor público que recebe recurso público tem que prestar contas. 
Ivonete (Codene): Faz um registro. Justiça não está sensibilizada para causas sociais - exemplo da inviabilização do feriado no 20 de novembro em Porto Alegre. No mérito o argumento foi que o feriado geraria prejuízo de 40 milhões e a pergunta de em quanto os negros contribuíram em milhões para a sociedade. Pede maior aprofundamento da questão do controle externo e posição sobre a questão de ouvidoria. Opinião sobre o Inquérito Policial que indica sobreposição de ação da Policia Civil e do Judiciário.

Luan (Movimento Negro): Qual a avaliação sobre ações afirmativas? Como avaliam a derrubada do feriado de 20 de novembro em Porto Alegre?

Maria Encarnación (Movimento Comunitário): Pede esclarecimento sobre os critérios utilizados pelos juízes para tomar as decisões. Ex: pensão alimentícia.

João Abílio (IAJ): Se focássemos mais na questão do serviço judicial, não poderíamos estar ajudando na des-construção da aristocracia presente $\mathrm{e}$ na democratização do Judiciário?

Charles (Amencar): Ouvidoria é uma alternativa fundamental. Viés popular no controle externo do Judiciário. Inquérito - é fundamental pensar a integração das ações. Ademais, acha fundamental ampliar o aporte das diversas ciências humanas para dar suporte às decisões judiciais. Fundamentação do caso do feriado denota a serviço de quem está a justiça. Contextualização das decisões da justiça é fundamental.

Sadek (CEBEPEJ): Ouvidoria é um lugar para fazer denúncias com recursos para proteção dos denunciantes. Controle externo tem que ver com controle administrativo no poder judiciário, não para discutir sentença e decisão de juiz. Mas, cabe discutir como é feita a formação dos juízes, tanto a básica quanto a permanente. Controle externo da polícia é feito pelo Ministério Público, mas isto tem gerado grandes conflitos. Ações afirmativas: para garantir direitos sociais elas são fundamentais e tendem a ajudar a promover maior igualdade atendendo a setores vulneráveis. Prestação jurisdicional como serviço é fundamental.

João Abílio (IAJ): A administração dos tribunais é feita por juízes. Considerando que, por natureza juízes tem outra atribuição, seria possível pensar administradores públicos para o judiciário, com cargos específicos, deixando de ser feita por juízes.

Vânia (Juíza do Trabalho): Questão do quinto constitucional, representação da Ordem do Advogados (OAB), como fica o impeditivo de exercício da profissão? Sessões secretas do Tribunal, difícil aceitar.

Magali (Sindjus-RS): Concorda com a negação da súmula vinculante. Questão do Orçamento Participativo precisa ser estendido para a sociedade. Eleições dos tribunais: no RS é feita com a participação dos desembargadores. Sindicato defende a proposta de participação dos magistrados de primeiro grau, dos servidores, da sociedade civil.

Marcelo (AJO): Questão de Conselhos de Planejamento com iniciativa legislativa. Na questão das férias, é fundamental extinção das férias forenses e distribuição imediata dos processos.

Edson (Comissão de Serviço Público $A L-R S$ ): Extinção ou não da Justiça Militar.

Sadek (CEBEPEJ): Não haveria temor de que o fatiamento da reforma frustre as expectativas?

Paulo (MNDH): A questão da proteção dos direitos humanos parece exigir muito mais do que federalização de crimes, exigiria uma intervenção mais ampla neste tema. Refere-se ao debate sobre o Sistema Nacional de Proteção dos Direitos Humanos, proposto pelo Movimento Nacional de Direitos Humanos e aprovado pela VIII Conferência Nacional, no ano passado. Ademais, há uma hierarquia de saberes que se traduz na distribuição da justiça. Há um domínio do direito sobre outros campos do saber que, em geral os absorve a seu serviço. Hoje há um conflito com outro saber que pretende ser hegemônico, a economia, e com isso há uma postura de resistência da parte do direito.

Cardozo (Deputado federal PT-SP): Administração do poder: ainda é uma questão profundamente amadora em todos os poderes, já que tem um exagero de cargos de confiança e pouca força para cargos mais permanentes. É favorável a administradores técnicos para o Judiciário. Quinto constitucional é fundamental para oxigenar com outras carreiras, mas é necessário aprimoramento, apesar de não ter proposta consensuada. $\mathrm{O}$ Ministério Público está propondo quinto constitucional com prazo certo. 
Orçamento Participativo ideal que não seja só dos juízes. Mas teríamos que levar em conta todo o Orçamento da União. Não há ainda um modelo para isso. Modelo clássico da tripartição do poder: o grande desafio é o controle da sociedade sobre o poder. Isso precisa ser ampliado e exige maior formulação e criatividade. Concorda com Marcelo (AJD), especialmente com fim das férias forenses - há resistências dos advogados. Judiciário tem que ser transparente, forte e legitimado. É preciso distinguir bem prerrogativa de privilégio. Defende a extinção da justiça militar. Pergunta de Sadek angustia, pois mudanças pontuais podem cair no vazio, mas as globais podem não sair. Saída é passar claramente a ideia de que Reforma é um processo. Direitos Humanos falta um sistema processual com ações próprias e alargar campo de ação do Poder Judiciário, do Ministério Público e da Sociedade Civil. Acha um momento oportuno para aprofundar este debate.

Charles (Amencar): Fundamental abrir o Direito para outros campos do saber e especialmente para avançar na interdisciplinaridade, até porque isto permitiria ampliar as condições de proteção de direitos sociais.

Sadek (CEBEPEJ): Sublinha a questão da importância de ampliarmos este debate. Cumprimenta pelo debate promovido.

Cardozo (Deputado federal PT-SP): Pede desculpas pelo atraso na chegada. Ressalta que engajamento social é indispensável. Espera que esta seja a última Comissão de Reforma do Judiciário.

\section{CONTINUANDO OS DIÁLOGOS}

Na primeira parte, o Painel foi coordenado por Soraia Mendes (técnica da ONG Acesso Cidadania e Direitos Humanos e advogada de movimentos populares) e contou com a participação de Selma Teixeira da Silva (técnica da ONG União de Negros pela Igualdade - UNEGRO, de Porto Alegre) e Marcelo Semer (diretor da Associação dos Juízes para a Democracia - AJD e juiz de direito em São Paulo). Na segunda parte foi coordenado por Célio Golin (dirigente do Nuances, ONG que atua na Promoção dos direitos humanos de gays, lésbicas e travestis em Porto Alegre) e contou com a participação de Quintino Severo (presidente da Central Única dos Trabalhadores do RS) e de Jacques Távora Alfonsín (diretor da ONG Acesso Cidadania e Direitos Humanos, professor de direito na UNISINOS, RS). O painel foi realizado no dia 25 de novembro, das 14 às 18 horas.

\section{PRIMEIRA PARTE}

\section{SELMA TEIXEIRA DA SILVA (UNEGRO)}

Todos aqui já pensaram na Igualdade de Oportunidades? Ou nunca precisaram parar para pensar nesta premissa? Este é um dos objetivos que perseguimos, os militantes do Movimento Negro. Nesta busca é que o Acesso à Justiça, de uma forma mais ampliada, vai nos instrumentalizar. $\mathrm{O}$ significado de acesso à justiça para a sociedade brasileira, sob o olhar dos movimentos sociais, revela a necessidade urgente de uma busca de soluções que tornem a Justiça mais acessível a todos.

Sabemos que muitas reformulações foram feitas nas estruturas judiciárias, como, por exemplo, a criação de Juizados Especiais, o Estatuto da Criança e do Adolescente, como forma de dar celeridade a determinados tipos de ações, assim como nas legislações processuais. No entanto, muito ainda há que ser feito.

A entidade do Movimento Negro que represento, no seu $2^{\circ}$ Congresso Nacional, realizado este ano, apontou, no documento "Um olhar Negro Sobre 
o Brasil', inúmeras situações da realidade brasileira que poderão ser utilizadas como suporte e contribuição ao tema desenvolvido neste Seminário. Pretendemos, sob a ótica deste Movimento Social evidenciar fatos concretos, buscando indicar algumas soluções de caráter geral.

Ao longo da História podemos constatar que o Estado Brasileiro, ante a compromissos que os portugueses tinham com os ingleses e com a implantação da industrialização no mundo, jogou ex-escravos à margem do processo econômico, decretando o aprofundamento do racismo que se propagou sob o argumento de que os negros eram incapazes, indolentes, inábeis, preguiçosos e indisciplinados, não podendo assim ser absorvidos pelo mercado de trabalho formal. Desta forma, o racismo e a discriminação foram sustentados, fazendo com que milhões de negros e negras fossem esquecidos pelo Estado e pela Sociedade. Este fato se reflete nos dias atuais, impedindo o exercício pleno da cidadania, mesmo após os negros darem o seu sangue na construção deste país. A Exclusão Social é evidente.

Com o passar dos tempos, foi disseminado um ideário de nação, onde o mito da Democracia Racial impera, consistindo-se numa premissa de que todas as raças ou etnias, com seus costumes e tradições, convivem harmoniosamente, compondo uma nacionalidade pluralista.

O Movimento Negro, em sua luta árdua, contínua e mais recentemente o Movimento Sindical, de forma conjunta, mudaram a história. A Central Única dos Trabalhadores (CUT), em parceria com o Centro de Estudos das Relações do Trabalho e Desigualdades (CEERT) relatou à Organização Internacional do Trabalho (OIT)- que tem como princípios promover políticas sociais a nível internacional, desenvolver as oportunidades para que homens e mulheres tenham um emprego digno alargar a proteção social, dentre outros - apresentou denúncia de descumprimento pelo governo brasileiro da Convenção $\mathrm{N}^{\circ} 111$, que trata da discriminação no emprego e profissão). Desta forma, o governo foi obrigado a admitir publicamente a inexistência da Democracia Racial e que o Racismo é um problema estrutural.

O Governo também se viu obrigado a enfrentar de forma séria o racismo e a discriminação após a III Conferência Mundial contra o Racismo, ocorrida em Durban, na África do Sul, em 2001, da qual Movimento Negro participou e de cujas resoluções surtiram-se efeitos positivos no país, através dos compromissos assumidos pelo governo. No entanto, nossa mobilização ainda é necessária para que estes compromissos se efetivem.

Em face do preconceito racial e de outras formas de discriminação existentes, numa avaliação Pós-Durban, a Unegro denuncia, em suas resoluções, dentre outros pontos, com base no documento "Um olhar Negro Sobre o Brasil”, o que segue:

O racismo, a discriminação racial, a xenofobia, e outras formas de intolerância, estão estreitamente vinculados à pobreza, o subdesenvolvimento, a marginalização, a exclusão social e as desigualdades econômicas. A falta de oportunidades econômicas, de autonomia, de acesso aos recursos sociais, educacionais, culturais, constituem um quadro social histórico, no qual estão sujeitos os homens e mulheres negras.... Estas condições se estabelecem pela falta de vontade política, na inexistência de uma legislação eficiente, na falta de estratégias de aplicação de medidas concretas por parte do Governo, bem como pela permanência de atitudes preconceituosas, racistas e baseadas em estereótipos negativos.

A III Conferência Mundial Contra o Racismo, Discriminação Racial, Xenofobia e intolerância Correlata, ocorrida em 2001 na cidade de Durban, África do Sul, reafirma que os Estados Nacionais têm o dever de proteger e promover os direitos humanos e as liberdades fundamentais das vítimas do racismo, da discriminação racial, xenofobia e intolerância correlatas...

Enfatiza o vínculo entre direitos humanos e o respeito à diversidade cultural, instando os Estados a dotar medidas e estratégias afirmativas e positivas que venham a criar as condições necessárias à participação efetiva da comunidade de origem africana no processo de tomada de decisões e no exercício dos direitos civis, culturais econômicos, políticos e sociais, posto que esta luta por uma responsabilidade primordial do Estado, devendo este desenvolver planos de ação nacional para promover a diversidade, a igualdade, justiça social, a igualdade de oportunidades, a participação de todos e, principalmente, promover um maior conhecimento e um maior respeito pela sua herança histórica e cultural.

De outra parte, a Sociedade civil organizada se empenha na redefinição de estratégias para o combate às desigualdades tendo entre suas prioridades o planejamento, readequação e ampliação das políticas 
públicas. Porém, os dados divulgados por instituições de reconhecida credibilidade atestam, em linhas gerais, as insuficiências das medidas governamentais para reverterem o cenário radiográfico das condições de vida e morte dos não brancos na sociedade brasileira: a população afrodescendente está distribuída territorialmente em localidades de baixa potencialidade competitiva, elevadas taxas de repetência e abandono escolares, menor expectativa de vida, altos índices de mortalidade infantil e trabalho insalubre e de baixa remuneração.

Diante destas colocações, que de certa forma sintetizam o nível do debate transcorrido no Congresso, defendemos como proposições na área de Direitos Humanos:

a) Defesa dos direito das crianças e adolescentes com revisão do Estatuto da Criança e do Adolescente, extinguindo instituições que em nada as recuperam;

b) Na área da cultura, instituição de mecanismos legislativos que garantam uma política de conservação do patrimônio histórico da cultura africana;

c) Reconhecimento e titulação imediata, como forma de reparação histórica de todas as comunidades identificadas como quilombolas. Criação de programas de proteção dos recursos naturais locais, proibindo a ação pública ou privada que venha a gerar a depredação ou deslocamento destas comunidades. Assegurar recursos financeiros e técnicos para a implementação de infraestrutura definida democraticamente pela população remanescente de cada área;

d) Punição à intolerância étnico-religiosa que estigmatizam os cultos de origem africana de modo a assegurar o preceito constitucional que assegura o livre exercício religioso (direito a isenção de imposto, liberdade de culto);

e) Uma imediata reforma do sistema carcerário brasileiro, implantando uma ótica de recuperação e ressocialização dos detentos;

f) No campo da justiça e da defesa da cidadania, a reforma do Judiciário se faz necessária, com expansão das Defensorias Públicas e a promoção de mais profissionais para a assistência à população.
Mais Delegacias especializadas, casas de passagem, centros de defesa, especialmente para a defesa da mulher. Serviço Psicológico para homens agressores;

g) No campo institucional o cumprimento, por parte do governo federal, das determinações acordadas na última Conferência Mundial da ONU de Combate ao Racismo, Xenofobia, Preconceito e Discriminação e outras Formas de Intolerância, realizada na África do Sul em 2001;

h) $\mathrm{Na}$ área da comunicação, lançar uma campanha nacional de combate ao Racismo para dar suporte a um serviço 0800,0 Disque Racismo Nacional.

Com esta exposição, intencionalmente queremos demonstrar que os movimentos sociais constituem um sujeito coletivo que modifica o cenário político da sociedade, com planejamento e organização, politizando as múltiplas esferas do cotidiano.

Neste espírito de mobilização, a Unegro propõe uma ação conjunta para que se dê a Reforma do Judiciário, pensando na democratização do mesmo, atuando nas esferas governamentais do Poder Judiciário e com os Movimentos Sociais.

A Reforma do Judiciário perpassa pela Cidadania. O Judiciário deve estar cada vez mais a serviço dos cidadãos, promovendo sua defesa, permitindo o exercício de seus direitos, orientando-lhes. E para que a exclusão social das populações especiais, negros, não negros, índios, mulheres, jovens, idosos, portadores de deficiências e da, livre orientação sexual, minimize e com o passar do tempo se extinga se faz necessário uma ação conjunta, com a perspectiva de revolucionária mudança no tecido social.

Entendemos que o Acesso à Justiça está não muito distante da camada média e profundamente distante da inferior, na pirâmide social. Inúmeras são as causas. Nas camadas médias que detém $40 \%$ da renda nacional, os lucros obtidos nos meios de produção nem sempre são suficientes para suportar uma demanda judicial que vai onerar com custas processuais e honorários advocatícios. Nas camadas inferiores, ocorre a falta de informação, a falta de preparo intelectual, falta de autoestima, por 
todo um isolamento em que se encontram, por estarem alijados dos centros urbanos, mesmo para usufruir dos serviços da Defensoria Pública.

Acreditamos que o Acesso à Justiça será mais intenso quando o Judiciário se propuser a ter mais proximidade com os cidadãos, buscando realizar projetos entre as comunidades.

De forma a contemplar o maior número de populações especiais, considerando que nossa entidade é originalmente do movimento negro, mas de acordo com seus princípios é plurirracial, solidarizando-se com a luta de todos os movimentos sociais populares que se coloquem no campo progressista, propomos como sugestão:

a) Programas de formação aos operadores do Direito (Magistrados, Membros do Ministério Público e Defensoria Pública), direcionados à compreensão da invisibilidade da Comunidade Negra e à mudança deste contexto, cuidando igualmente de outras formas de preconceito e discriminação que atingem outros grupos sociais, com o intuito de aplicar estes conhecimentos em Varas a serem criadas pelo Judiciário, que tratem especificamente da Diversidade Cultural e Pluralismo Étnico à semelhança do que propõe O Senador Paulo Paim em seu Projeto de Lei que trata do Estatuto da Igualdade Racial. Estamos aqui reforçando esta necessidade.

b) Outra forma de proporcionar que os operadores estejam mais vocacionados às soluções das demandas seria o sistema de parcerias com Prefeituras que mantêm diversos Programas Sociais, desenvolvendo um trabalho direto de Assistência, Orientação aos necessitados

c) Da mesma forma, exigir como requisito de ingresso às carreiras do Judiciário, comprovação, em grau de estágio, em entidades ou instituições preocupadas com trabalho social, que também poderá ocorrer via Prefeituras.

d) Criar mecanismos para que as demandas sejam solucionadas em curto prazo de tempo, abreviando caminhos, evitando a morosidade na decisão das mesmas, seja por responsabilidade do procurador ou do próprio magistrado. e) Criar mais varas judiciais e consequentemente mais vagas aos profissionais, adequando o Judiciário conforme as exigências da realidade que se apresenta. Há municípios que exigem, para a solução do volume de trabalho, muito mais juízes que outros municípios menores.

f) Portanto, para finalizar, gostaria de dizer que o Judiciário é participe das mudanças que revolucionam a Sociedade e que venham a contribuir com a convivência entre os diferentes, para que ela seja usufruída deforma plena.

A vida é mudança, é ação, e o Poder Judiciário deve se adequar às mudanças, com menos formalismos, mais proximidade e criação de instrumentos jurídicos que tornem a justiça mais rápida e eficaz.

\section{MARCELO SEMER \\ (AJD)}

A Associação dos Juízes para a Democracia (AJD) é a favor de uma profunda reforma do Judiciário. Incomoda-se, no entanto, quando vê a reforma do Judiciário colocada no jogo da reforma do estado que o mercado quer.

A atual é a melhor Constituição que já tivemos. As reformas que dela tem sido feitas, em geral, a pioraram. A ideia de reforma indica que a Constituição está ruim. Ademais em boa medida o paradigma das reforma é refratário à ideia de Estado Democrático Social que está na Constituição. Em geral reduziram o poder do Estado e ampliaram o poder do mercado. Reforma não é necessariamente avanço, aliás, em geral tem piorado o perfil do Estado brasileiro.

Reforma do Judiciário pode ter o mesmo sentido? Documento do Banco Mundial exige previsibilidade e eficiência do judiciário, o contrário produz riscos e que o Judiciário deve garantir direitos individuais e da propriedade. Esta interpretação não coincide com os que defendem uma reforma do judiciário em vista da ampliação do acesso. Por isso, a ideia de Reforma é plurívoca.

Reforma do Judiciário que esteve em debate no governo Fernando Henrique tem uma matriz ruim, pois verticaliza o Judiciário (peça forte na súmula vinculante). Aluízio Nunes Ferreira, relator à época, propôs até a 
volta da avocatória, a introdução da questão da Ação Declaratória de Constitucionalidade e a verticalização administrativa, no Conselho Superior. Temas históricos da democratização do judiciário foram simplesmente deixados de lado. É bom fazer a reforma, mas há percalços. Se tivéssemos feito a reforma com FHC teríamos piorado o Judiciário e não melhorado.

O que seria importante garantir. Começar tudo do zero e que seja uma reforma radical do Judiciário, como foi dito pelo Min. Tomaz Bastos?

Há uma crise de legitimidade e de eficiência do poder judiciário que precisam ser enfrentadas.

A ideia de um Tribunal Constitucional é fundamental para aliviar o STF de questões comuns e preservá-lo para temas mais importantes. Hoje está na linha direta recursal em todos os sentidos. Sua tarefa de julgar Ações Diretas de Inconstitucionalidade não é cumprida, só consegue julgar liminares. É fundamental que seja modificado o formato de escolha dos Ministros, pois há necessidade de debate público sobre o tema.

Como abrir o Judiciário à sociedade? Como a sociedade controla o Judiciário? Não agrada a ideia de criação de uma grande corregedoria para punir juízes. Mais importante que isso é abrir para a transparência administrativa. É a regularidade da ação que está em crise e não as perversões. A criação de conselhos de planejamento e ouvidorias estaduais, regionais e federal, com membros do Judiciário e fora dele é fundamental. A sociedade precisa poder contribuir na formulação das políticas do Judiciário. Importância de que esses órgãos possam ter iniciativa legislativa, o que permitiria introduzir mudanças sem a vontade da cúpula do poder. Ouvidorias independentes são fundamentais.

Justiça é altamente desigual e desequilibrada: o mais forte (estado ou poderoso) leva sempre vantagem. Importante enfatizar a ideia da assistência jurídica plena, que exige levar o conhecimento do Direito às pessoas e a ter uma Defensoria Pública eficaz, como política pública, com vinculações orçamentárias ou com completa independência ou com sistema de metas.

\section{DEBATE}

Magali (Sindjus - RS): Concorde que o STF é um tribunal político - o que denota possibilidade de decisões mais políticas do que constitucionais - e que deve haver mudanças no processo de escolha. Pede a Marcelo qual a opinião sobre as propostas da súmula vinculante e de súmula impeditiva de recurso.

Soraia (Acesso): Há questões processuais que deveriam ser utilizadas. O movimento negro desmascarou o mito da democracia racial e que o racismo existe e deve ser criminalizado (referindo-se a decisão sobre o 20 de novembro). Hoje se avança para compreendê-lo do ponto de vista institucional. Não basta abranger estrutura do Judiciário, é preciso avançar na discussão do ensino jurídico e com ampliação da presença de negros (hoje só $2 \%$ ) neste lugar. O Tribunal de Justiça do RS tomou decisão com base em petição que falava em ócio e indolência no tocante ao feriado do 20 de novembro.

Selma (Unegro): Chama atenção para o debate sobre o Estatuto da igualdade racial e indica que há alterações a serem feitas em todas as áreas.

Marcelo (AJD): Não critica a reforma, acha que o governo está querendo fazer uma reforma cada vez mais tímida. O que está sendo proposto não muda radicalmente. Talvez seja importante tirar o STF da linha recursal em vista de uma hipótese de que possa escolher as causas que vai julgar. O STF é um órgão político, dizendo o que é Direito. Por isso, é preciso democratizá-lo estabelecendo mandato. Questão do racismo é delicadíssima. Questão do racismo e da tortura não tem reforma de lei a fazer, o que tem que fazer é reformar a cabeça do juiz. AJD fez curso de direitos humanos para juízes, a experiência foi interessante e hoje há cursos regulares no Tribunal de Justiça de SP. Há preconceito racial de classe que faz parte das decisões dos juízes. Importância de democratização do judiciário, a fim de evitar compadrio. Abrir este processo vai permitir maior transparência. Bom juiz é garantidor do direito fundamental e faz isso como um serviço público. Quanto maior o torniquete na independência do Juiz, mais difícil de fazer a balança pender para o social. Sobre a súmula vinculante é radicalmente contra. Súmula Impeditiva de Recurso não necessariamente resolve o problema. Decisões administrativas do executivo já resolveriam profundamente o problema da eficiência e da celeridade. Um dos maiores clientes do Judiciário é o Instituto Nacional de Seguridade Social (INSS), que faz isso para não pagar direitos reconhecidos. Ações coletivas: há um posicionamento refratário sobre isso no Judiciário, sendo que grande parte cai por razões processuais; há necessidade de aprimorar os 
mecanismos para qualificar isso; e a jurisprudência tem obstáculos também para ações em direitos difusos.

Flávio (Angola): Gostaria que fosse aprofundada a fala sobre julgamento do 20 novembro.

Paulo (MNDH): Há temas tabus para o Judiciário. Exemplos: tortura, racismo, violência contra a mulher e criança. Como enfrentar melhor estes temas? Importância de incluir temas de direitos humanos na formação permanente dos juízes e inclusive como exigência para o ingresso na carreira.

Virgínia (Themis): Como trabalhar a questão da cultura e a formação do conjunto dos operadores do judiciário?

João Abílio (IAJ): Comenta a questão dos temas tabus, enfrentá-los será que não seria uma boa maneira de dar maior visibilidade aos conflitos (torná-los visíveis para além do teatro do judiciário)? A mentira da igualdade de todos no sentido formal, quando no Judiciário, precisa ser denunciada.

Soraia (Acesso): Sobre a decisão do feriado de 20 de novembro em Porto Alegre: já se avançou no fato de aceitar que o movimento negro seja assistente de ação. Visibilidade do conflito já dá grande base para denunciar o racismo institucional. As derrotas jurídicas talvez possam ser transformadas em vitórias políticas.

Selma (Unegro): Fundamental fortalecer a organização social como mecanismo de promoção da igualdade racial.

Baldino (Associação Meio Ambiente POA): A OAB e o Ministério Público pregam controle externo, mas não aceitam fazê-lo nelas mesmas.

Marcelo (IAJ): Concorda com a ideia de direitos humanos ser tema de concurso público dos operadores do Judiciário. Lembra do fato de que recentemente foi retirado do concurso da Procuradoria de São Paulo com a alegação de que não haveria autonomia científica no tema. Juiz tem uma função didática em relação à polícia. Mandado de Busca e Apreensão Coletivo tem sido um absurdo de uso da força com os pobres e é absolutamente ilegal. Para o juiz, a questão da confissão não tem tido muito valor. Grande debate constitucional será o das ações afirmativas no caso dos negros. Juiz não foi feito para administrar dinheiro do judiciário.
Aplicação dos recursos públicos é tarefa coletiva, pois o dinheiro é público. Princípio da isonomia exige acabar com foro privilegiado (que lembra ordenações filipinas)

\section{SEGUNDA PARTE}

\section{QUINTINO SEVERO \\ (CUT-RS)}

Agradece o convite do IAJ, cumprimenta pela iniciativa e ressalta que o tema é um grande desafio, especialmente porque poucas pessoas tem acesso a ele de verdade.

Se o acesso à justiça é um problema, outro é que as pessoas também têm um acesso muito difícil ao debate sobre o tema e, especialmente, sobre a reforma do judiciário. A Central Única dos Trabalhadores (CUT) tem uma posição favorável à Reforma e entende ser necessário reformular o

Judiciário. Mas, ressalta que é preciso ter clareza sobre reformar para que e para quem.

Nossa opinião é que a reforma venha para atender melhor a sociedade e para democratizar o Poder Judiciário.

Minha fala será bastante política porque não tenho o acúmulo que os juristas, técnicos, desde ontem têm apresentado no debate. Falo na tentativa de fazer várias provocações. O central é pensar um Judiciário, acima de tudo, capaz de atender a todos(as), que de fato não seja por corporação, mas que seja e atenda a demanda de todos nós.

Primeiramente, falarei de uma palavra que talvez gere arrepio, ao menos no poder constituído, a questão do controle externo do poder judiciário. Mas, quando falamos em controle, precisamos definir bem o que é controle externo. Quando falamos disso não estamos nos referindo à interferência no poder do juiz julgar. Falamos da possibilidade de que os juízes mantenham a sua autonomia, a sua isenção no papel de julgar. Mas, o controle externo precisa incidir sobre questões administrativas e orçamentárias: O que é feito do orçamento do Judiciário? Quem é que dirige e como dirige? Como faz? 
Ademais, três questões são básicas para que efetivamente o juiz possa estar protegido no seu papel de julgar: a) a inamobilidade, ele não pode ser transferido de um lugar para outro por motivo de um julgamento que tenha desagradado este ou aquele segmento; b) a irredutibilidade, que é a garantia dos seus vencimentos não terem prejuízo; c) a vitaliciedade que é a garantia que o juiz permaneça como juiz, independente da posição que ele tenha. $\mathrm{O}$ controle externo e a reforma não podem mexer com estas questões.

Então, quando se fala no controle externo está-se exatamente falando para questões administrativas, porque, querendo ou não, o poder judiciário é um poder da República e precisa ter participação e transparência necessária para que a sociedade saiba com que e o que se passa dentro dele. O debate corporativo recentemente veio à flor da pele, quando do debate da Previdência - a CUT teve posição contrária à Reforma. Ficou clara uma contradição, os mesmos juízes que declararam ilegal a grave dos trabalhadores da Petrobrás em 1995, agora atuam em sua própria defesa.

Sem falar na declaração de greve, que gerou uma instabilidade institucional significativa.

É importante também discutir sobre como a sociedade olha o Judiciário; como ela dialoga com esta reserva, digamos assim, de Justiça atribuída ao Judiciário. Por outro lado, precisamos também enquanto cidadãos, fazer um debate da dependência que o povo tem do Poder Judiciário e também dos advogados.Temos que superar a ideia de que o cidadão é incapaz ou ele não tem a capacidade de se auto defender ou de resolver seus próprios problemas, tem que estar sempre o pai estado ou a mãe ou o pai judiciário protegendo, ele não pode ter sua autodefesa e autoorganização perante o poder constituído.

A segunda questão que problematizaremos é como o Poder Judiciário pode ser mais aproximado da sociedade, da comunidade, e esta do Judiciário. Um pequeno parêntesis, nesta sexta-feira, dia 21, quando paramos em frente do Tribunal para entregar uma carta dos companheiros/as que sofreram uma verdadeira invasão no acampamento do MST em Arroio dos Ratos. Imediatamente que chegamos, as portas e as grades se fecharam. Mas não é só o Judiciário, os demais poderes também estão cada vez mais afastados da sociedade, cada vez mais cercados de grades, de portões e de sistemas eletrônicos de proteção. Aí a pergunta: de quem estão se protegendo? Afinal, se o poder cumpre a lei, não precisa ter medo do cidadão?

Perguntava em outros painéis por que tanta jurisprudência neste país. Bastaria cumprir a lei, olhando sinteticamente, que com certeza não haveria necessidade de se criar tanta jurisprudência. Este também deve ser um dos grandes debates na reforma do Judiciário. Como é que faz cumprir a lei sem que seja necessário criar outros instrumentos que muitas vezes acabam complicando e transformando o poder judiciário em um poder moroso, levando as pessoas muitas vezes e especialmente em casos trabalhistas, sabendo que vai demorar e perder, a preferir acertar a pendência trabalhista por $50 \%$ do valor da ação para não ficar 8 ou 10 anos esperando da Justiça, prefere perdera metade do passivo trabalhista para imediatamente receber. A série de instrumentos e recursos e de jurisprudência que se cria, sem falar na necessidade de ter um advogado ou ter alguém que o proteja ou que o represente perante o poder judiciário, acaba afastando cada vez mais o cidadão do Judiciário. Com estes comentários, acho que começamos a responder a pergunta sobre o afastamento da população do Judiciário. Não é que a maioria da população desconheça o Judiciário. Ela se afasta dele por conta das barreiras que são cada vez maiores.

Outro elemento que também intriga é a falta de conhecimento. Ou seja, não há visibilidade para sociedade sobre como é que funciona um fórum, um tribunal. É necessário disponibilizar mais informação para a população, que o Judiciário tenha o mínimo de visibilidade. Não se trata de querer interferir na decisão do juiz, mas de saber como é que funciona esta máquina.

Outro aspecto que acho que ainda está presente no nosso poder judiciário é a herança maldita da monarquia. O Judiciário ainda conserva aquela visão do rei que indica os julgadores para julgar a favor do rei. É possível entender nesse sentido a forma de nomeação no Supremo (STF).

Pesquisa feita pela $\mathrm{OAB}$ e recentemente publicada pela Revista Isto É demonstra um pouco que a sociedade confia pouco no Judiciário: é a quinta instituição. É difícil aceitar isso. Considerando esta situação, pensa que a sociedade deveria criar instrumentos e movimentos participar na reforma do Judiciário. Propõe que a sociedade apresente a sua proposta, talvez até como uma emenda de iniciativa popular. 
Apresentamos aqui uma série de ideias que não chegam a ser uma proposta fechada; elas são sugestões para o debate. E preciso que a reforma do Judiciário seja mais que um remendo superficial.

Sinteticamente nossas propostas são: a) transformar o STF num tribunal constitucional, composto por doze membros indicados por 4 setores, com 3 cada: Executivo, Legislativo, Judiciário e sociedade; b) Sobre os tribunais superiores, uma proposta antiga da CUT é que não vemos necessidade de ter um tribunal superior do trabalho, por exemplo, mantendose o STJ e TSE; c) criar o Conselho de Justiça com objetivo de integrara sociedade no poder judiciário e ao mesmo tempo fiscalizá-lo administrativamente, em todas as esferas e hierarquias do Judiciário, composto de forma paritária e respeitando a proporcionalidade de um quarto distribuídos igualmente entre magistrados, servidores, Ministério Público e $\mathrm{OAB}$ (juntos) e sociedade civil, com função de escolher os membros diretores do Fórum ou dos Tribunais entre os magistrados votados naquela instância, a fiscalização do cumprimento do estatuto da magistratura e das políticas judiciárias definidas; a fiscalização dos atos administrativos praticados pelos membros dos organismos diretores; decidir sobre a proposta de aplicação orçamentária. Neste ponto, pode-se pensar mais amplo, a fim de tornar o processo de definição e fiscalização orçamentária mais participativo; d) Mandatos fixos para os desembargadores e ministros dos Tribunais, isto permitiria maior renovação.

O tema é novo, nós da CUT também temos poucas elaborações, mas estamos abertos ao debate e propondo algumas ideias para tornar as coisas um pouco diferentes, e para melhor. Queremos trabalhar na perspectiva de um Judiciário melhor, mais atuante, mais rápido, mais eficiente e que possa responder às demandas da sociedade, que são muito grandes e bastante complexas.

\section{JACQUES TÁVORA ALFONSIN (ACESSO)}

Cumprimenta carinhosamente todos os presentes e coordenadores do evento. Pede desculpas pois fará uma brevíssima exposição em quatro pontos que tem como norte a complexidade do tema do acesso à Justiça. Estamos diante de um problema muito sério, pois lida com o que há de mais sagrado na pessoa humana: a garantia dos seus direitos humanos fundamentais. Reconhece a legitimidade das propostas apresentadas por seu antecessor.

Informa que partirá da experiência que desenvolve na ONG onde atua, a Acesso Cidadania e Direitos Humanos. Parte de quatro questionamentos:

a) O acesso é garantido a quem efetivamente precisa dele? No nosso país quem é o sujeito de direito que tem acesso ao Judiciário? Quem é essa pessoa afinal de contas? Como é que se garante o acesso?

b) O que essas pessoas buscam? O acesso é feito em busca do que efetivamente? Qual é a finalidade? O que elas buscam no Judiciário?

c) O acesso é permitido por alguém? Quem é que tem competência para permitir o acesso ao Judiciário? Como é que isso é tratado pela lei, pelas instituições?

d) O acesso pode ser imposto? E se ele pode ser imposto, é imposto a quem, quem é que o impõe, nós podemos impor a alguém esse acesso?

Comecemos pela primeira. Estamos acostumados a ouvir as expressões massa, povo, pessoa, cidadão, organização, pessoa jurídica e assim por diante, numa palavra se pudéssemos reunir aqueles que procuram nossas ONGs diríamos que são vítimas da violação dos direitos humanos fundamentais. É a estas a quem queremos garantir acesso à Justiça. A vítima é alguém contra quem foi praticada uma injustiça, às vezes individual, mas na maior parte das vezes coletivamente, abrangendo uma classe inteira. É gente que cata material para sobreviver; é gente que não temo que comer; é gente ferida na sua etnia, como é o caso dos negros; é gente ferida na sua orientação sexual. Toda esta gente quer alguma forma de socorro.

Muitos juristas, em nome da igualdade formal, dizem que tratar desigualmente as pessoas, identificando-as como vítimas, é atribuir-lhes um déficit na sua cidadania. Portanto, o positivismo de dizer que todos são iguais perante a lei impede o reconhecimento da vítima como ela efetivamente está e o socorro que deve ser prestado a ela. Socorre-se da lição de um juiz paranaense, Eulas Continje, que diz que a transposição dos conceitos que estão previstos abstratamente na lei para a realidade engessam as situações jurídicas. Desde a Revolução Francesa se faz a distinção entre pessoa e cidadão. A Declaração dos Direitos do Homem e do Cidadão fez-se em nome da cidadania, que seria justamente aquele 
acréscimo à pessoa. Na expressão precisa de Hannah Arendt, a cidadania é o direito a ter direitos. Infelizmente, exatamente este conceito de cidadania é que serve para barrar o acesso aos direitos da cidadania. Esta abstração, junto com questões processuais, geralmente impede a discussão dos direitos humanos sociais em juízo e cria este tipo de barragem. Portanto, discutir acesso é garanti-10 às vítimas. Abrindo-lhes espaço de poder, acesso o empoderamento- como dizem as mulheres latino-americanas que cunharam este termo extraordinário.

Sobre a segunda questão: o acesso busca socorro, solução para injustiças sofridas. A vítima vai ao juiz em busca de um valor, a Justiça. Ela nem sabe o que é a lei e o que a lei diz a respeito dela, por isso não é em busca do cumprimento da lei que vai a juízo. Ela vai a juízo em busca de Justiça, valor que permeia todo o ordenamento jurídico. A lei existe em função destes valores. O Estado e a sociedade civil organizada, como diz Pontes de Miranda, existe em função dos direitos humanos fundamentais. Eles não estão nem atrás nem do lado nem na frente da lei, eles estão acima da lei e é por isso que eles têm que permanecerem qualquer discussão relacionada com qualquer conflito que seja levado ao judiciário. Essa questão da justiciabilidade dos direitos humanos fundamentais, eu posso reclamar em juízo. Os direitos sociais, por exemplo, permeiam todo o ordenamento e estão presentes em qualquer conflito em qualquer lide que discuta direitos humanos.

Se fosse para ver exclusivamente cumprida a lei, bastaria o raciocínio da lógica formal para resolver os impasses. A grande questão que os movimentos sociais estão colocando é que a liberdade cresce e muda de rumo dia a dia e que é a aplicação cega da lei que constrói a injustiça, a chamada desordem institucionalizada, como dizia Roberto Lima Filho. No caso da terra, por exemplo, foi por não ter uma medida preventiva à expansão ilimitada da propriedade privada contra a função social da propriedade que institucionalizou a desordem que esta aí. É exatamente contra esta desordem que os negros reclamam que estão sendo discriminados. É contra esta desordem que os direitos sociais são reclamados. Então, a desordem é fruto da noção de justiça puramente comutativa, como troca de coisas e de quantidades. A justiça distributiva é qualitativa, vê a desigualdade e quer corrigir a desigualdade, a urgência dos que clamam contra a desordem pede uma justiça efetivamente distributiva.
Esses valores da justiça não são possíveis de definição precisa, não sendo à toa que o ordenamento se expresse em tantos conceitos jurídicos em branco. Por exemplo, o de função social da propriedade, tão discutido, tão ignorado e tão negado na sua eficácia. Kelsen diz, que em geral tem sido invocado contra os direitos humanos, nas primeiras palavras de um livro em que pergunta $o$ que é a justiça: Quando Jesus de Nazaré foi conduzido perante Pilatos e reconheceu que era rei disse: Nasci para dar testemunho da verdade e para isso vim ao mundo. E Pilatos perguntou: $\mathrm{O}$ que é a verdade? O procurador romano esperava uma resposta a esta pergunta e Jesus não deu. Já que dar testemunho da verdade não era a essência de sua missão divina, como o rei messiânico Jesus havia nascido para dar testemunho da justiça, a justiça do reino de Deus e por esta justiça morreu na cruz. Com este simples raciocínio, no mais famoso julgamento da história, mostra que, quando Pilatos virou as costas para Jesus, sem ouvir nada, e no silêncio de Jesus, na interpretação do jurista gaúcho Rui Cirne Lima, está a ideia de que a verdade é uma vítima enquanto a justiça não recuperar a identidade com a reparação das injustiças praticadas contra as vítimas. Ela não tem como se legitimar.

Sobre a terceira questão: se o próprio titular dos direitos humanos não se convencer que ele é o principal responsável pelo respeito devido aos seus direitos humanos fundamentais e que não adianta ficar esperando isso da lei, dos poderes públicos, dificilmente a situação muda. O titular dos direitos é o principal responsável sim. A dignidade humana é inalienável e indelegável. Não podemos transferir dignidade. Este é o grande problema que afeta os pobres quando alguém chega ao escritório de advocacia e pergunta: mas quem sou eu doutor para tomar tal ou qual atitude. Isto mostra em que medida já perdeu as condições de recuperação sua dignidade própria. $\mathrm{O}$ melhor serviço que podemos prestar diante desta pergunta é saber que ele é o primeiro responsável pelo acesso e pelo respeito a si próprio e aos outros. Estes direitos são universais, são de todos, são dos negros, são dos brancos, dos ricos, dos pobres. Não há desigualdade em matéria de dignidade humana. Enquanto isto não for estendido a todos, o Estado fracassou e a sociedade como um todo fracassou. É preciso levar a sério o parágrafo único do artigo primeiro da Constituição Federal que diz que é do povo que emana todo o poder. $O$ povo tem que ser identificado pelo alcance da dignidade.

Os famosos direitos econômicos, sociais, culturais e ambientais é que nos dão a dimensão da concretude das vítimas, e a situação em que a vítima 
vai em busca de justiça e o judiciário lhe oferece o cumprimento da lei. Neste sentido, somam-se dois problemas de meio: o primeiro representado pela linguagem e o segundo pelo devido processo legal. Dalmo Dallari, num livro muito oportuno, mostra o quanto a linguagem impede o judiciário de compreender o que está se passando com as vítimas. Muitos juízes sequer percebem a inadequação de fazer perguntas a pessoas simples ou sem conhecimento jurídico usando expressões técnicas e ficam irritados quando não recebem uma resposta precisa.

Lembra o caso de um juiz trabalhista que insistiu em perguntar a um modesto auxiliar de padaria, se era verdadeiro que ele havia incorrido em desídia. Obteve com resposta o silêncio apavorado do depoente. O juiz concluiu com a afirmação de que o silêncio era por má fé. Por outro lado, o próprio juiz muitas vezes não consegue entender com precisão o vocabulário do depoente, deixando lacunas no termo de depoimento ou registrando coisas diferentes daquelas que foram ditas.

Em grande medida esta postura está ligada a uma atitude de superioridade em relação às pessoas comuns e à falta de percepção de que, muito mais do que um aparato formal, a magistratura bem exercida é um serviço relevante prestado ao povo. Está em questão, aqui também trocar o poder dominação pelo poder serviço. Esta postura distancia o juiz do povoe, em última análise, prejudica a apuração da verdade e a realização da justiça, reduzindo a utilidade e o prestígio do judiciário.

Sobre o respeito ao devido processo legal, pergunta: será que se obedece o devido processo legal quando é para defender o próprio patrimônio - um latifundiário se socorre do Código Civil para dizer pode proteger à bala o seu patrimônio. Toda a luta dos movimentos populares é para fazer valer a dignidade humana, que é muito superior ao patrimônio. Declara que tem divergência com juristas defensores de direitos humanos que acham que em qualquer caso é preciso sempre respeitar o devido processo legal. E da opinião que a defesa da vida não pode depender de um devido processo legal. A questão de fundo é saber até que pondo o devido processo legal está a serviço do processo social. Difícil admitir que tem que cumprir todas as rubricas necessárias para ter direito a comer, a vestir, a morar, a sobreviver. A necessidade não pode ficar para depois, não pode depender da nossa vontade: ou comemos e moramos, ou morreremos. Como vem dizendo um grande jurista alemão, Friedrich Muller, a falta de pão e de teto é a maior prova de que nosso Estado ainda não é nem Democrático e nem de Direito. Porque o Estado Democrático de Direito é aquele que democratiza os bens da vida e não só o voto.

Outro exemplo relacionado com o devido processo legal: o juiz é um cidadão como qualquer outro e, fora da sala de audiência, tem todo direito de visitar a vítima e de conhecer sua realidade. Exemplo disso foi quando o Núcleo de Estudos Críticos da Magistratura do Rio Grande do Sul fez uma visita a um assentamento dos Sem Terra. A reação foi grande, houve até quem defendesse que estes juízes não fossem mais acolhidos na AJURIS. Certamente a reação não teria sido a mesma se a visita tivesse sido feita à FARSUL (Federação da Agricultura do RS). Portanto, existe um perfil classista claramente, perfeitamente, identificado na magistratura, que também precisa ser vencido pela nossa persistência e pela nossa luta. Não é possível mudar de repente a cabeça do juiz, mas de tanto a gente bater, algo novo pode acontecer.

Sobre a última questão, se o acesso pode ser imposto, e a quem ele pode ser imposto. Que pergunta mais difícil esta! Os direitos humanos fundamentais não têm apenas eficácia vertical, eles não são válidos somente contra o Estado, eles são válidos também contra os outros, contra a sociedade civil, inclusive, contra os empresários. Quando um juiz, como aconteceu com um dos juízes deste Núcleo de Estudos, numa sentença inicial de uma possessória ou de uma reivindicatória, exige que o proprietário demonstre que cumpre com a função social da propriedade, está impondo um acesso. É o descumprimento da função social da propriedade. No conteúdo da função social da propriedade está o respeito devido aos direitos humanos fundamentais.

Conclui dizendo que reconhece que está com gente que trabalha com o movimento popular e por isso invoca uma pessoa que lembra com a maior saudade e com maior respeito, um professor de filosofia, aqui do RS, perseguido pela Revolução Militar, o Dr. Ernani Maria Fiori. Ele diz: "em regime de dominação de consciências, os que mais trabalham menos podem dizer a sua palavra e multidões imensas nem sequer têm condições para trabalhar. Os dominadores mantém o monopólio da palavra com que mistificam, massificam e dominam". Para dizer em outras palavras, se alguém quer dizer a sua palavra tem que lutar para tomá-la, aprendera tomá-la dos que a detêm e a recusam. É difícil, mas este aprendizado é imprescindível. E a pedagogia do oprimido que um encontro como este quer garantir. 


\section{SISTEMATIZANDO OS DIÁLOGOS}

Sistematizar é organizar, de acordo com alguns critérios, pontos nucleares do debate. É exercício de interpretação. Por isso, é nossa intenção, como relator dos debates, tomando em conta alguns critérios, as posições apresentadas no debate e alguns temas da conjuntura do debate nacional sobre a Reforma do Judiciário, apresentar uma sistematização. Informamos, desde já, que ela não substitui a leitura e a riqueza das opiniões e dos aspectos que se encontram nas exposições. Quer muito mais servir de chave de leitura para elas. Neste sentido, não será exaustiva e abordará aspectos que a nosso juízo consideramos relevantes.

Organizaremos a sistematização em três grandes critérios: 1) Diagnóstico do Judiciário e do Acesso à Justiça; 2) Justificativa para Reformar ou não o Poder Judiciário; 3) Propostas defendidas, aqui elegendo algumas mais referenciadas nos debates e presentes no debate nacional sobre o assunto. Dentro de cada critério, procuraremos apontar ênfases, convergências e divergências. Mais do que mapear opiniões e posições interessa-nos situá-las. Eventualmente faremos referências aos que as defenderam. Mas faremos o possível para não operar desta maneira, visto que nem sempre as opiniões e posições foram explicitamente colocadas sobre todos os assuntos, o que dificulta este exercício.

\subsection{DIAGNÓSTICO DO JUDICIÁRIO E DO ACESSO À JUSTIÇA}

Observaremos dois aspectos: a compreensão conceitual e a análise da situação desses dois temas.

Sobre a compreensão conceituai, verifica-se uma complementaridade entre Judiciário e Acesso à Justiça, considerando que o segundo é elemento fundamental do primeiro, mas é mais amplo. Ou seja, a compreensão da maioria dos participantes dos diálogos aponta para a ideia de que acesso à justiça é mais do que acesso ao Judiciário. Esta noção está baseada numa ideia ampla de justiça que trabalha aspectos de acesso a condições humanizadas de vida e entende o acesso ao Judiciário como um dos mecanismos disponíveis à cidadania para que possa mediar conflitos que se apresentam no processo de realização da justiça. Poderíamos dizer que o acesso à justiça, neste sentido, é responsabilidade do conjunto dos poderes do
Estado e também das organizações da sociedade civil. O Judiciário tem uma parcela desta responsabilidade, sobretudo no sentido de prover condições para que o próprio acesso à justiça em sentido mais amplo possa ser ou não tornado demanda de mediação judicial. Havendo, no entanto, dúvidas e divergências sobre o real potencial deste poder incidir de maneira significativa nesta perspectiva, até porque há posições que entendem a necessidade de criar mecanismos sociais de mediação que não levem a uma judicialização da vida em sentido amplo.

No que diz respeito à noção de acesso à justiça no âmbito do Judiciário, a compreensão é que estão em jogo pelo menos dois aspectos: a) a disponibilização de mecanismos e instrumentos; b) a construção de uma cultura ou o conhecimento popular destes e do próprio poder Judiciário. Observa-se, portanto, que, para a maioria dos participantes, acesso à justiça é mais do que previsão de igualdade formal ou de formalismos legais que assim o determinem. Exige materialidades que traduzam o acesso concretamente de forma tangível para os mais pobres e historicamente discriminados, de modo especial. Nisto pode-se também entender o segundo aspecto. Ou seja, há uma clara percepção de que o Judiciário é desconhecido tanto na sua estrutura e funcionamento geral quanto no que diz respeito aos mecanismos e instrumentos de acesso a ele. Em suma, acesso à justiça é condição estruturante de promoção concreta da cidadania e de realização dos direitos humanos.

A compreensão comum é de que o Judiciário é um dos poderes republicanos e que, como tal, mesmo tendo uma natureza específica que o distingue dos demais, para a maioria, deveria caminhar para uma atualização que exatamente possa justificá-lo desta maneira. Ou seja, há uma compreensão de que, mesmo sendo poder republicano com natureza específica, haveria necessidade de qualificá-lo, a fim de superar resquícios de autoritarismo e aristocracia que persistem. Não há divergências sobre a importância do Judiciário ser fortalecido e, de modo especial, ser aproximado da vida da comunidade. É comum a opinião de que a ampliação do acesso à justiça, associada à modernização e agilização de procedimentos e processos qualificaria a institucionalidade democrática em nosso País.

No que diz respeito ao diagnóstico da situação, é comum a avaliação de que há problemas estruturais de acesso à justiça e de que o Judiciário precisa avançar em agilidade, credibilidade e efetividade, além de outros 
aspectos. Há uma avaliação unânime de rechaço às posições que defendem a adequação do Judiciário aos ditames mercadológicos patrocinados pelo Banco Mundial. Há também um claro rechaço a constituição de uma justiça para os pobres e outra para os ricos, o que denota de modo especial a necessidade de qualificação do acesso à justiça, sobretudo aos mais pobres e historicamente discriminados. Há também uma consciência de que são múltiplos e complexos os fatores que contribuem para que o Judiciário ainda seja pouco acessível e atenda aos mais pobres. Há também uma consciência clara e comum de que a autonomia e independência dos juízes são elementos determinantes para preservar o caráter de imparcialidade da Justiça. No entanto, há uma crítica consistente no que diz respeito à confusão entre imparcialidade e neutralidade, já que há uma exigência de que os juízes sejam profundos conhecedores dos conflitos e da situação social, além do conhecimento do arcabouço legal. A decisão do juiz é mais do que a aplicação formal da lei, suas decisões são sempre contextualizadas e demandam uma carga forte de interpretação, o que remete para a não aceitação da posição de neutralidade. Há também concordância sobre a necessidade de qualificar e até simplificar mecanismos processuais a fim de inibir recursos protelatórios de decisão, considerando o argumento que isto, em geral, tem servido apenas para favorecer a parte mais forte nas contendas judiciais. Ademais, mesmo sem muito consenso, há uma apreciação sobre a necessidade de superação da postura patrimonialista que tem inibido uma compreensão e aplicação da justiça em sentido mais amplo. Isto vale tanto para a constituição do arcabouço legal quanto para a jurisprudência e a processualística. Outro aspecto que é amplamente rechaçado é o corporativismo que marca a postura e em boa medida as decisões do Judiciário. Há reconhecimento sobre a necessidade de um certo sentido de corpo, como é comum a qualquer instituição. No entanto, o exagero corporativo é indicado como um dos componentes da resistência à mudança $\mathrm{e}$ à atualização, muitas vezes até do tipo administrativo e de contratação de pessoal, que se manifestam em pelo menos dois aspectos mais tangíveis, o nepotismo e o investimento mais amplo em informatização, por exemplo.

Há um reconhecimento da importância de medidas como a criação de Juizados Especiais, o que tem facilitado o acesso e agilizado os procedimentos. No entanto, há divergência e oposição a propostas que obriguem a tramitação de todos os processos que se enquadrem nos parâmetros dos Juizados Especiais, inibindo a possibilidade de sua tramitação pela justiça comum. Há ainda quem pense que seja necessário não somente criar Juizados Especiais para os casos de menor monta e defenda a criação de Juizados Especiais ou até a des-judicialização de questões de grande monta, que envolvem, por exemplo, contendas entre grandes agentes econômicos.

No que diz respeito ao processo administrativo do Poder Judiciário, observa-se claramente propostas de modernização e de ampliação da participação. Seja no processo de decisão sobre alocação e aplicação de recursos, considerado obscuro e enviesado, já que, por exemplo, há manifestações claras de que a opulência dos tribunais poderia ser substituída pelo investimento em informatização. Ainda sobre a administração há quem defenda que seja feita por técnicos concursados para tal, deixando de ser tarefa de magistrados. No tocante a composição da direção dos tribunais há uma clara demanda por democratização na forma de escolha e na superação do critério exclusivo de antiguidade e mérito. No tocante à forma de ingresso há unanimidade sobre a importância de fortalecer a via do concurso, inclusive com defesas no sentido de sua qualificação e até de sua uniformização. Há rechaço às terceirizações explícitas ou "bradas" e a toda e qualquer forma de nepotismo direto ou transversal.

No tocante ao acesso, há uma análise quase unânime de que é um dos principais gargalos, sobretudo para os mais pobres e discriminados. Ou seja, há deficiências de compreensão do próprio poder Judiciário, o que inibe o acesso e também dificuldades de estrutura de suporte, como a de defensores públicos disponíveis. Há neste ponto posições comuns de defesa da necessidade de ampliação e qualificação das defensorias públicas e também de sua constituição com maior independência. Um terceiro aspecto é o da linguagem, também apontado como elemento inibidor. Ou seja, em.geral a linguagem tecnicista afasta as pessoas da compreensão de questões muito elementares. Ademais, a ausência de formação e educação cidadãs sobre a legislação e o poder judiciário, de modo geral, afastam a população da compreensão do linguajar tecnicista que marca o Judiciário. Há também um diagnóstico de que persiste a confusão sobre o papel constitucional do Ministério Público na promoção de ações de proteção de direitos, apesar de todos os avanços que já podem ser identificados no sentido de ampliar e qualificar a atuação deste em questões coletivas. Os Juizados Especiais ampliaram e facilitaram o acesso à justiça. Mas, há avaliações de que 
persistem neles um conjunto de ritualísticas e procedimentos que afastam a população da compreensão de suas decisões. Identificaram-se também experiências construtivas de socialização do saber e até de mediação de conflitos que tem ampliado o conhecimento e as condições de acesso popular à Justiça, como é o caso das Promotoras Legais Populares, entre outros exemplos.

A vigilância cidadã sobre o Poder Judiciário também tem crescido, através da organização de Observatórios do Judiciário, por exemplo. No entanto, há uma constatação geral de que tanto as organizações da sociedade civil quanto a população em geral, ainda estão muito longe de incidir, de discutir e de ter propostas mais consistentes e amadurecidas sobre o tema.

Em suma, sobre o acesso à justiça, em sentido estrito, a avaliação é de que precisa ser enfrentado como uma das prioridades urgentes para tornar o Judiciário mais próximo da comunidade, de modo especial dos mais pobres e historicamente discriminados, e para que a comunidade possa compreender e agir, se assim entender necessário, por essa via na solução dos conflitos. Note-se que há uma preocupação com a não transformação do Judiciário na principal mediação dos conflitos, apesar dos dados mostrarem aumento de demandas judiciais, há resistências à ampliação da judicialização, como já apontamos acima. Por outro lado, qualificar o acesso é promover condições concretas para que a população possa decidir sobre e quando lhe convém acessá-lo e, se assim, decidir, que possa contar com todos os recursos e mecanismos, da melhor qualidade, para fazê-lo.

Em linhas gerais, pode-se dizer que o diagnóstico aponta para a necessidade de mudanças no Poder Judiciário.

\subsection{REFORMAR O JUDICIÁRIO?}

Salvas as divergências sobre abrangência e profundidade, é unânime a opinião da necessidade de reformar o Poder Judiciário.

As divergências de abrangência podem ser identificadas em posições que defendem uma reforma ampla que democratize no sentido da participação direta da população na escola de dirigentes e de definição de prioridades administrativas e outras que defendem apenas ajustes procedimentais (exemplo, mudanças no processo ou na administração mais profissionalizada). Intermediariamente a estas, estão posições que conjugam as duas, com mais ênfase para um ou para outro dos extremos.

As divergências de profundidade podem ser identificadas quando se trata de resistir à Súmula Vinculante e defender a independência do juiz, com as quais todos parecem concordar, mas, ao mesmo tempo, advogar a necessidade de agilizar a prestação da justiça com o fortalecimento de juizados especiais como caminho comum para casos de menor vulto. Ainda neste ponto, há os que defendem que mudanças legislativas seriam suficientes para produzir efeitos positivos no trabalho do Judiciário, sem haver necessidade de reforma constitucional e os que defendem estas reformas, mas acreditam também na necessidade de reforma do judiciário. Em suma, este pequeno exercício de explicitação de divergências serve para mostrar que os posicionamentos sobre a reforma do Judiciário são os mais diversos e atendem a interesses distintos.

Considerando estas divergências, pode-se, no entanto, notar que a defesa da reforma do Judiciário indica que ela deveria vir para:

a) Ampliar e qualificar o acesso à justiça: Mostrando claramente a contradição que exclui os mais pobres do acesso a ela e facilita $o$ acesso aos poderosos, exigindo, portanto, uma reversão estrutural na forma de prestação jurisdicional que permitisse o acesso em condições de igualdade reais.

b) Democratizar o poder: A superação de posturas e práticas aristocráticas e antidemocráticas na organização do poder Judiciário e a criação de condições de maior transparência e controle público emergem como desafios fundamentais. Afinal, democratizar o Judiciário mostra-se como requisito nuclear para consolidar o processo de democratização do país.

c) Agilizar suas decisões: Esta finalidade não comunga com a manutenção de estruturas de empobrecimento de recursos para uns e de manutenção de exagero de recursos para outros ou com a proposição de mecanismos que engessem a renovação da interpretação na aplicação da lei. Incide centralmente na ideia da qualificação e renovação da estrutura de processo e na defesa de mudanças de competência dos tribunais superiores. 
d) Tomá-lo mais próximo da comunidade: Especialmente dos mais pobres e historicamente discriminados, seja na possibilidade de acesso, na forma de operar a linguagem, na contextualização das decisões e, especialmente na capacidade de oferecer defesa e promoção dos direitos humanos fundamentais.

Em linhas gerais, portanto, a Reforma do Judiciário, para as organizações da sociedade civil viria para fortalecer a democracia e a proteção dos mais fracos.

\subsection{PROPOSTAS}

O elenco de propostas que deveriam ser contempladas na Reforma do Judiciário é amplo e controverso. Não há unanimidade sobre quais seriam exatamente as propostas a serem defendidas, quais seriam prioritárias ou quais não teriam apoio de qualquer tipo. Várias propostas foram apresentadas, muitas discutidas, outras apenas indicadas. Talvez o espírito do Seminário, construído na base de diálogos, tenha contribuído para não fechar posições e sim para abri-las. De qualquer forma, tomando em conta o debate que está colocado no Congresso Nacional e na sociedade, colhemos algumas questões nucleares e sistematizamos alguns pontos de proposição, com a anotação das devidas divergências.

\section{Controle externo}

De todas esta seguramente é a questão mais polêmica. Há desde posições que se opõe a ele plenamente, até as que o defendem de forma ampla, passando por outras que o defendem em marcos intermediários. Todos rechaçam qualquer tipo de controle externo sobre a decisão do juiz e a intervenção no conteúdo das decisões. A maioria entende ser necessária alguma forma de controle externo de questões administrativas. Entre os que defendem o controle externo nestes moldes, todos defendem a constituição de organismos que contemplem a participação de magistrados e de organizações de fora do Poder Judiciário. Alguns defendem que além destes, também participem servidores do Poder e também cidadãos comuns em maior número que os magistrados.

\section{Ingresso e saída}

Há uma defesa clara da necessidade de fortalecer a forma de ingresso unicamente por concurso (inibindo as contratações por interesse que facilitam o nepotismo). Sobre este ponto há propostas que defendem a unificação dos concursos e outras que mesmo não entrando no mérito desta proposta, entendem que seja necessário avançar na qualificação dos conteúdos a serem exigidos, incluindo-se, por exemplo, temas de direitos humanos. No que diz respeito à saída há defesa da quarentena como recurso necessário, como forma de impedir tráfico de influência e outros problemas a ela assemelhados.

\section{Defensoria Pública}

É unânime a defesa da proposta de ampliação, qualificação e de maior independência para a Defensoria Pública. Esta proposta é apontada como um dos principais instrumentos para qualificar o acesso à justiça para os mais pobres. Não há acordo sobre a maior ou menor especialização destes órgãos.

\section{Súmula vinculante}

Há acordo na rejeição da proposta de Súmula Vinculante. Todos a entendem como instrumento que no afã de agilizar, resultaria em engessamento da ação do juiz e no cerceamento de sua autonomia e, sobretudo, na necessária renovação na aplicação do direito. Em suma, tenderia a tomar o Judiciário ainda mais conservador. Há dúvidas e divergências sobre a implementação da Súmula Impeditiva de Recurso, apesar de haver maior simpatia a esta.

\section{Democratização do Judiciário}

Todos concordam com a necessidade de democratização do Judiciário. No entanto, há divergências sobre sua amplitude: há os que defendem somente a ampliação do fórum de escolha dos dirigentes dos tribunais para o conjunto dos magistrados, outros que defendem a ampliação também para os servidores e até os que, mesmo sem explicitar, 
gostariam de ver juízes eleitos pela população. Há uma clara defesa da ampliação da participação (para uns somente os magistrados, para outros incluindo servidores, para outros ainda toda a sociedade) nas decisões sobre alocação de recursos e físcalização dos gastos, com defesa de orçamento participativo no Judiciário, por exemplo. Além disso, há unanimidade sobre a necessidade de democratizar o acesso à justiça, especialmente promovendo condições objetivas para que os mais pobres e historicamente discriminados possam acessá-lo quando o desejarem e com bons serviços.

\section{Tribunais Superiores}

A principal proposta é a de transformação do Supremo Tribunal Federal em tribunal constitucional. No entanto, o debate não foi aprofundado, de tal forma que não se pode identificar grandes divergências em relação à proposta, mas também não há grandes defesas dela.

\section{Competências em Direitos Humanos}

Há uma clara defesa da necessidade de ampliação da capacidade e acolhida dos temas e questões de direitos humanos pelo Judiciário. A leitura é de que os direitos humanos deveriam se constituir numa das matérias de maior relevância na prestação da justiça. Há divergências sobre a federalização dos crimes contra os direitos humanos. Todos concordam que esta não é a única solução para qualificar a ação do Judiciário neste tema. Mas, há entendimentos de que pelo menos esta medida permitiria um tratamento mais consistente do tema. Em suma os que a defendem concordam com a proposta de iniciativa de avocação pelo Ministério Público Federal e decisão do Supremo.

\section{Processualística}

Mesmo sem esboçar propostas concretas, há uma defesa comum da necessidade de produzir modificações no Processo, de tal forma a impedir o excesso de recursos protelatórios - que somente servem para isso e para nada mais. Há divergências, no entanto, se isto deveria ser feito com alterações nos Códigos de Processo ou se isto poderia ser feito com ajustes pontuais ou até com decisões administrativas - sobretudo no âmbito do Poder Executivo, um dos que mais utiliza recursos deste tipo. Outro ingrediente que aparece nesta questão é a necessidade de equilibrar o ritual e o mérito no tocante às decisões, já que há uma avaliação de que em boa medida tem pesado mais o primeiro que o segundo.

\section{Acesso à Justiça}

Neste ponto há unanimidade sobre a necessidade de qualificar e ampliar o acesso, sobretudo para os mais pobres e discriminados historicamente. Há propostas que indicam alterações estruturais e outras que apontam para a necessária facilitação e aproximação, o que produziria mudanças significativas, mas sem grandes intervenções estruturais. No campo da primeira, está o fortalecimento e qualificação dos Juizados Especiais (não havendo acordo sobre a exclusividade), a interiorização da Justiça com a criação de Varas e Juizados fixos ou itinerantes, a extinção da necessidade de defensor para casos mais simples (proposta não completamente consensual), a desjudicialização de contendas entre grandes agentes econômicos (proposta pouco aprofundada), a ampliação, qualificação e independência da Defensoria Pública, a ampliação da atuação do Ministério Público em questões coletivas, entre outras medidas. No campo do segundo, estão propostas como a de reformulação das abordagens e da linguagem, facilitando a compreensão popular da justiça, a ampliação do conhecimento sobre o acesso e a prestação da Justiça com a inclusão de temas como estes no processo educacional, a formação de agentes populares de promoção do acesso à justiça, a instituição e reconhecimento de mecanismos informais de mediação de pequenos conflitos, a aproximação maior dos juízes das situações e do contexto onde atuam, entre outros aspectos. Finalmente, é profunda a aspiração comum de que garantir acesso à justiça é dar passos significativos na promoção dos direitos humanos e nas condições de acesso à sua proteção, sobretudo para as populações mais pobres e discriminadas.

Como dissemos inicialmente, a intenção não é construir uma pauta ou agenda de propostas da sociedade civil, sendo exaustivo e condensando toda a riqueza e a pluralidade do debate. $\mathrm{O}$ que fizemos é apenas um exercício de organização das diversas ideias e propostas que marcaram os 
debates. Certamente este exercício está longe de contemplar o conjunto das aspirações e das proposições. No entanto, como também já dissemos, que sirva como chave de leitura dos diversos diálogos que foram realizados e que certamente continuam. 